Review

\title{
Antibody Conjugates: From Heterogeneous Populations to Defined Reagents
}

\section{Patrick Dennler ${ }^{1}$, Eliane Fischer ${ }^{1}$ and Roger Schibli ${ }^{1,2, *}$}

1 Center for Radiopharmaceutical Sciences, Paul Scherrer Institute, 5232 Villigen PSI, Switzerland; E-Mails: patrick.dennler@psi.ch (P.D.); eliane.fischer@psi.ch (E.F.)

2 Department of Chemistry and Applied Biosciences, ETH Zurich, 8093 Zurich, Switzerland

* Author to whom correspondence should be addressed; E-Mail: roger.schibli@psi.ch; Tel.: +41-56-310-2837.

Academic Editor: Dimiter S. Dimitrov

Received: 13 June 2015 / Accepted: 14 July 2015 / Published: 3 August 2015

\begin{abstract}
Monoclonal antibodies (mAbs) and their derivatives are currently the fastest growing class of therapeutics. Even if naked antibodies have proven their value as successful biopharmaceuticals, they suffer from some limitations. To overcome suboptimal therapeutic efficacy, immunoglobulins are conjugated with toxic payloads to form antibody drug conjugates (ADCs) and with chelating systems bearing therapeutic radioisotopes to form radioimmunoconjugates (RICs). Besides their therapeutic applications, antibody conjugates are also extensively used for many in vitro assays. A broad variety of methods to functionalize antibodies with various payloads are currently available. The decision as to which conjugation method to use strongly depends on the final purpose of the antibody conjugate. Classical conjugation via amino acid residues is still the most common method to produce antibody conjugates and is suitable for most in vitro applications. In recent years, however, it has become evident that antibody conjugates, which are generated via site-specific conjugation techniques, possess distinct advantages with regard to in vivo properties. Here, we give a comprehensive overview on existing and emerging strategies for the production of covalent and non-covalent antibody conjugates.
\end{abstract}

Keywords: immunoglobulin; bioconjugation; antibody conjugates; chemical conjugation; enzymatic conjugation; non-covalent antibody conjugates 


\section{Introduction}

The introduction of the "magic bullet" principle by Paul Ehrlich at the very beginning of the 20th century and the following work of Köhler and Milstein on the production of the first mouse monoclonal antibodies in 1975 gave rise to the development of a novel class of therapeutics [1]. Today, monoclonal antibodies cover the majority of recombinant therapeutic proteins used in the clinic while many more are in clinical trials [2,3]. However, the therapeutic effects of unmodified antibodies are often not curative, especially in cancer therapy, and so researchers started to focus on methods to arm antibodies with cytotoxic entities, giving rise to antibody drug conjugates (ADCs) [4,5] and radioimmunoconjugates (RICs) [6]. In contrast to ADCs that carry a cytotoxic drug, RICs are armed with suitable therapeutic radionuclides. To date, only four therapeutic antibody conjugates have made it onto the market, namely "Mylotarg ${ }^{\circledR}$ (withdrawn)", Adcetris ${ }^{\circledR}$, Kadcyla ${ }^{\circledR}$ (ADCs) and Zevalin ${ }^{\circledR}$ (RIC). Nevertheless, there are several promising candidates in early and advanced clinical phases [7-9]. At the same time, monoclonal as well as polyclonal antibody conjugates are important tools for a variety of in vitro assays that are indispensable for research, including Western Blot analysis or immunofluorescence.

It is of high importance to select the most appropriate conjugation technique according to the final purpose of an antibody conjugate [10]. Random conjugation via amino acids is often sufficient enough for antibodies that are used for in vitro assays where it is only important to maintain the binding affinity and specificity towards an antigen. Conversely, antibody conjugates that are used for medical applications have more stringent requirements. In addition to an unaltered binding affinity, it has become evident that the site of modification and the payload-to-antibody ratio (PAR) need to be controlled as both parameters can dramatically influence the pharmacokinetic, safety and therapeutic efficacy [11-13].

Different sites within the structure of an antibody can be targeted to generate antibody conjugates (Figure 1). As proteins are based on an amino acid backbone, conjugation via reactive natural or engineered residues is the most obvious method. The difficulty, however, is to control the stoichiometry of chemical reactions with lysine or cysteine residues, which are the two most commonly targeted amino acids for bioconjugation. The products of chemical conjugation via lysines or cysteines are usually a mixture of species with different PARs. Additionally, heterogeneity is not only created by different antibody-to-ligand ratios but also by different sites of conjugation. Depending on the purpose, certain antibody conjugates require a clearly defined uniform population to help to reduce batch-to-batch variability and possible impairment of antibody conjugates' characteristics [11,12]. Hence, much effort has been made to find and establish antibody conjugation strategies that enable us to better control stoichiometry and site-specificity. Some of the approaches require site-directed mutagenesis while others are more complicated as they include multiple enzymes or combine protein expression machineries from different hosts. These techniques are in general more time consuming compared to a classical chemical conjugation approach since the primary sequence of the antibody has to be altered or additional proteins have to be expressed.

In contrast to various other recently published reviews [9,14-19], this review does not report exclusively on bioconjugation strategies for ADCs but comprehensively summarizes currently available antibody conjugation methods with a focus on newly emerging technologies. 


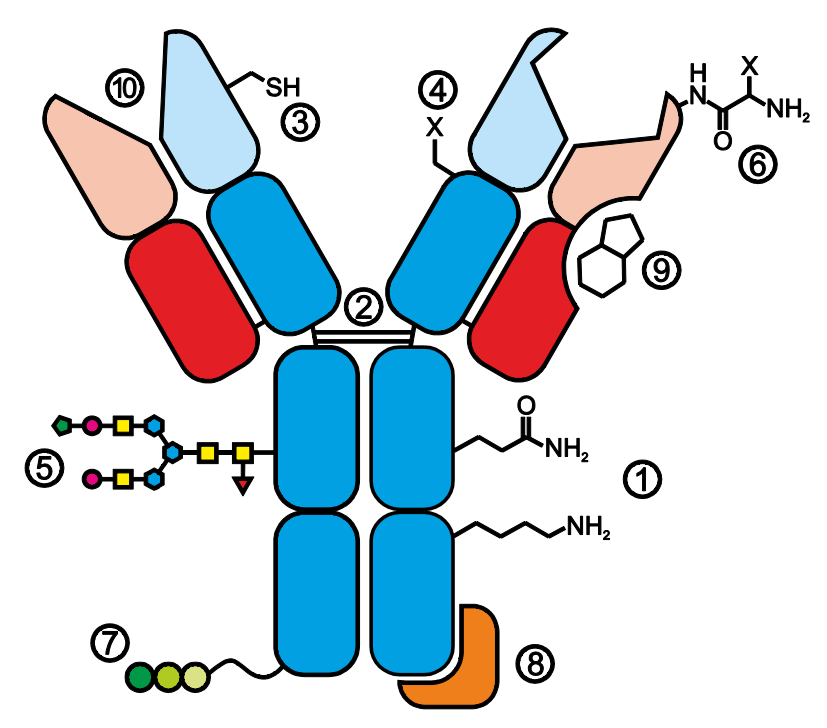

Figure 1. Antibody conjugates can be generated by targeting natural amino acids (1) including interchain disulfides (2), engineered cysteines (3), non-natural amino acids (4), the carbohydrate moiety (5), the N-terminus of heavy and light chain (6) or engineered tags (7). Strong protein-protein interaction, i.e., Fc-binding domains (FcBD) can be used to form noncovalent antibody conjugates (8). Additionally, the nucleotide binding site (NBS) is a valuable antibody modification site for photoaffinity labeling (9) and antibodies with catalytic activity (10) can be exploited to form bioconjugates where the coupled pharmacophore, e.g., a peptide assumes the targeting function and the antibody acts as a cargo molecule.

\section{Conjugation via Natural Amino Acid Residues}

In theory, bioconjugation is possible via most amino acids [20-25]. Nevertheless, the nucleophilic primary amine of lysine and reactive thiol of cysteine are the most commonly used amino acids in the bioconjugation of antibodies and are still the current method of choice. Additionally, tyrosine and selenocysteine have also been exploited as reactive sites for antibody modification (Figure 2).

\subsection{Conjugation via Lysine}

Lysine is one of the most commonly used amino acid residues for linking substrates to antibodies, because they are usually exposed on the surface of the antibody and are thereby easily accessible. Alkylation and acylation are the most important reactions with the nucleophilic $\varepsilon$-amine [22]. Antibodies can contain up to 80 lysine residues [26] and, as a consequence, conjugation via lysines inevitably leads to a twofold heterogeneity: (i) different number of substrates per antibody and (ii) antibodies with the same number of substrates attached at different sites [27,28]. Furthermore, modified lysines in proximity to the antibody-binding site may influence the interaction of the IgG with the corresponding antigen. The heterogeneity with respect to stoichiometry can be controlled or limited to a certain extent by adapting the molar ratio of ligand and antibody used in the reaction and with respect to site-specificity by the chemical accessibility of reactive groups [29-31]. 


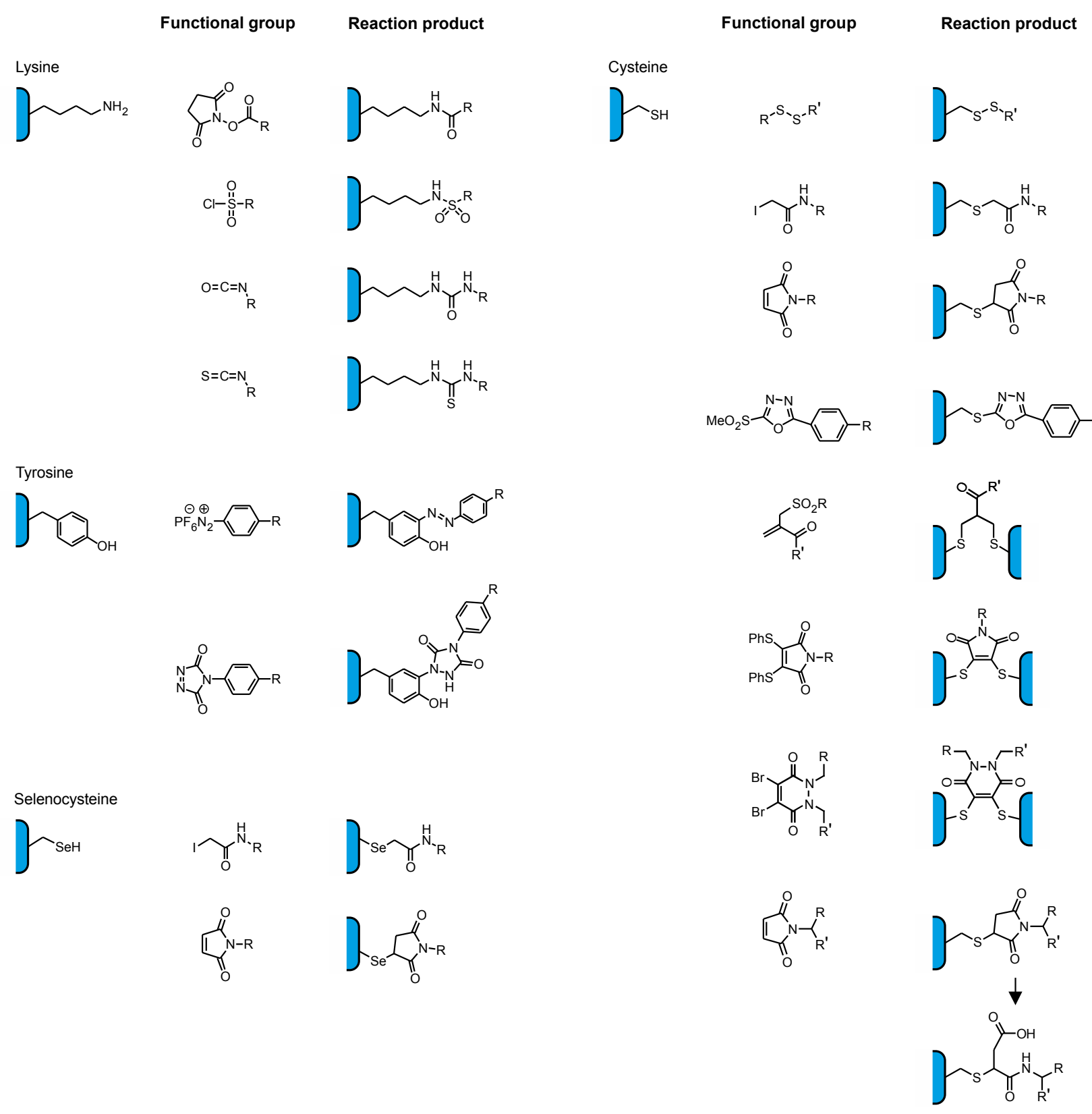

Figure 2. Overview of functional groups and their reaction products with the corresponding amino acid residue.

Lysines are typically modified with N-hydroxysuccinimide (NHS) esters, sulfonyl chlorides, isocyanates and isothiocyanates. From a countless number of lysine-coupled antibody conjugates, for both in vitro and in vivo applications, gemtuzumab ozogamicin (Mylotarg $®$ ) was the first antibody-drug conjugate (ADC) on the market. A semi-synthetic calicheamicin derivative was equipped with an NHS ester in order to conjugate the toxin to lysines of a humanized IgG4 [32]. However, due to a lack of improvement in clinical benefit to patients, Mylotarg ${ }^{\circledR}$ was withdrawn from the market in 2010. Currently, there are two clinically relevant antibody conjugates that are generated by lysine modification: (i) the ADC trastuzumab emtansine (Kadcyla ${ }^{\circledR}$ ), and (ii) the radioimmunoconjugate (RIC) ${ }^{90}$ Y-ibritumomab tiuxetan (Zevalin ${ }^{\circledR}$ ). Whereas the drug was attached to the antibody via a heterobifunctional crosslinker [33], an isothiocyanate-functionalized chelator was used to accomplish an antibody conjugate that can be labeled with the therapeutic radioisotope ${ }^{90} \mathrm{Y}$ [34]. 
Although NHS esters are widely applied, it should be noted that they can also react with other amino acids such as threonine, tyrosine, serine and cysteine or with the N-terminus of an antibody $[35,36]$. In contrast to the stable amide bond between NHS esters and lysine residues, bonds that are formed with those amino acids can be labile and susceptible to hydrolysis. As a result, the premature release of the toxic drug from the ADC can lead to unwanted side-effects [37].

\subsection{Conjugation via Cysteines}

\subsubsection{Native Cysteines}

In contrast to lysines, the number of cysteine residues within the sequence of IgGs is much lower. There are only four interchain disulfide bonds that can be targeted as potential conjugation sites and thus, the heterogeneity of immunoconjugates can be dramatically reduced. Moreover, these cysteines exclusively form covalent disulfide bonds to stabilize the tertiary structure of the antibody [38-41] and are therefore, under non-reducing conditions, not reactive. Sun et al. took advantage of the fact that the susceptibility of different disulfide bonds in an antibody towards reduction varies [42] and developed two strategies that enabled tighter control of the site of conjugation. While partial reduction with either dithiothreitol (DTT) or tris(2-carboxyethyl) phosphine (TCEP) predominantly yielded conjugates where ligands were attached to heavy-light chain disulfides, partial re-oxidation with 5,5'-dithiobis (2-nitrobenzoic acid) (DTNB) yielded conjugates where ligands were mainly attached to heavy-heavy chain disulfides [43]. McDonagh et al. developed a different approach to control the site modification by replacing four or six of the interchain cysteines with serine, thereby reducing the number of accessible cysteines to either four or two. Accordingly, stoichiometric homogenous antibody conjugates with clearly defined site of ligand attachment could be generated [44].

Classically, cysteine residues can be modified through disulfide exchange or addition to electrophiles such as maleimides and iodoacetamides [22,23,25]. Alkylation of thiols with iodoacetamide is predominantly used in order to prevent the formation of disulfide bonds (possible crosslinking) after reduction of an antibody and is therefore often required for analytical purposes. The most frequently used cysteine-based conjugation strategy uses maleimide-functionalized reagent or linkers. While the number of conjugates for both in vitro and in vivo applications is, as for lysine-based approaches, unlimited, only one antibody conjugate where conjugation via cysteine was employed is clinically relevant. Brentuximab vedotin (Adcetris $\left.{ }^{\circledR}\right)$ is an ADC, which was generated by the conjugation of a maleimide-functionalized drug to the reduced interchain cysteines of an anti-CD30 antibody [45].

Recently, various novel cysteine-reactive functionalities have been developed [46]. Patterson et al. developed a sulfone-based linker that exhibited, when conjugated to an antibody, superior stability compared to the corresponding maleimide-based linker [47]. Godwin and co-workers presented an alternative thiol conjugation approach where bis-sulfone-functionalized reagents are used to form a stable three-carbon bridge with disulfides. In addition, the structure of the antibody remains intact and the ligand-to-antibody ratio can be tightly controlled $[48,49]$. Researchers in the labs of Chudasama, Baker and Caddick describe two different bridging approaches whereby they developed both a novel class of maleimides, designated as next generation maleimides, and successfully generated ADCs with all the aforementioned advantages [50,51] in addition to using pyridazinedione derivatives to generate 
dual-modified ADCs [52]. This technology can be used to site-specifically attach two different functionalities onto an antibody while benefiting from the aforementioned advantages of bridging approaches. In addition, Lyon and Tumey have both developed novel maleimide-derivatives that undergo rapid thiosuccinimide ring hydrolysis and are then no longer prone to maleimide elimination processes [53,54].

\subsubsection{Engineered Cysteines}

The incorporation of additional unpaired cysteine residues into the backbone of an antibody is a valuable strategy towards improved homogeneity of antibody conjugates. Stimmel et al. used this approach and replaced a serine in the $\mathrm{CH} 3$ domain with a cysteine. Controlled reduction conditions enabled them to generate RICs by site-specifically attaching a chelating system exclusively to the two additional cysteines while all other cysteines in the antibody backbone remain unaffected [55]. A similar approach was exploited by Junutula and co-workers to develop homogeneous ADCs. The resulting defined drug-to-antibody ratio (DAR) of approximately two led to an improved therapeutic index compared to the corresponding ADC that was produced by conjugation via interchain disulfides [56,57]. The absence of ADCs with a high DAR is most likely the reason for these results.

Additionally, the site of conjugation influences the stability of the bond between the toxin and the cysteine [58]. Sites where the cysteine is only partially accessible and surrounded by positively charged amino acids promoted succinimide ring hydrolysis, resulting in better stability of the conjugate. In contrast, solvent-exposed and easily accessible cysteines were prone to a maleimide exchange process with albumin, cysteine and glutathione both in vitro and in vivo [58].

Although cysteine-based bioconjugation represents a valuable tool for site-specific and stoichiometric uniform antibody modification, some aspects have to be considered: (i) The introduction of novel solvent-exposed cysteine residues can influence the aggregation behavior of the expressed antibodies as the reactive thiols can form disulfide bonds between immunoglobulins [59,60] and (ii) The thioether between maleimide and cysteine can undergo exchange and retro-addition processes in the presence of other thiols, e.g., albumin or glutathione that can influence the in vitro but more importantly the in vivo performance of the antibody conjugate $[58,61,62]$.

\subsection{Conjugation via Selenocysteine}

Rader and co-workers cotranslationally inserted selenocysteine, a cysteine analogue, into the C-terminus of IgG1 Fc fragments. The selenol group ( $\mathrm{pKa} 5.2$ ) endows selenocysteine with more nucleophilic chemical properties, enabling specific reaction with electrophilic moieties (maleimide, maleimide-like or iodoacetamide) in the presence of other amino acids, including cysteine (pKa 8.3) [63]. Moreover, reduction of the antibody is no longer required and hence, interchain disulfides will remain unaffected. By generating stoichiometrically uniform antibody conjugates with biotin, fluorescein and poly(ethylene glycol) as a proof of concept, they demonstrated the utility of their technology for the development of novel antibody conjugates [64-66]. 


\subsection{Conjugation via Tyrosine}

Surface accessible tyrosines are rare and are therefore an attractive site for bioconjugation. By using cyclic diazodicarboxamide derivatives such as 4-phenyl-3H-1,2,4-triazole-3,5(4H)-dione (PTAD), Ban et al. established an efficient click-like tyrosine ligation and successfully conjugated PTAD-functionalized substrates to trastuzumab [67,68]. Recently, they described a novel approach to conjugate via tyrosine residues in which diazonium hexafluorophosphate reagents are used to selectively modify trastuzumab. However, experiments with $\mathrm{N}$-acyl methylamides of histidine, serine, cysteine, tryptophan and lysine revealed reactivity the latter two towards cyclic diazodicarboxamid. In addition histidine, tryptophan and unoxidized cysteine exhibited reactivity towards a diazonium hexafluorophosphate derivative [69,70]. Even if both reagents exhibit a high chemoselectivity for tyrosine, side reactions with other amino acids are inevitable.

\section{Conjugation via Bioorthogonal Amino Acid Residues}

As an alternative to natural amino acids, non-canonical amino acids (NCAA) are valuable handles for site-selective protein labeling since they display a chemical functionality that is orthogonal to the functionalities found on natural amino acids [71]. Technologies to incorporate NCAAs require rearrangement of the antibody sequence and thus the exact localization and number of NCAA in the expressed protein can easily be controlled and changed.

Schultz and co-workers are pioneers of cell-based approaches to incorporate NCAA into proteins, including antibodies [72,73]. Their technology relies on the introduction of an orthogonal tRNA/aminoacyl-tRNA synthetase pair, which, in combination with $p$-acetylphenylalanine (pAcF), was exploited to express NCAA displaying antibodies (Figure 3). In a second step, oxime ligation with alkoxy-amine derivatized auristatin yielded homogeneous ADCs with defined sites of drug attachment $[13,74]$. Recently, they presented an extension of their technology whereby they incorporated two distinct NCAA into the same antibody, pAcF and azido-lysine (AzK). The two functionalities enabled them to site-specifically conjugate a toxin and a fluorescent dye [75], giving rise to an approach could be an attractive basis for endowing antibodies with toxins that exhibit different cell-killing mechanisms, thereby increasing the potency of ADCs. Although quantitative yields could be accomplished, the reaction conditions of the oxime ligation are rather harsh for antibodies and could potentially lead to aggregation [76-78].

Open cell-free synthesis (OCFS) is a novel technology to incorporate NCAA into antibodies that, in contrast to the cell-based approach, does not use intact living cells [79-81]. The protein is synthesized by mixing cell extract (providing essential cell organelles) with chemical substrates (nucleoside triphosphates, amino acids, salts and co-factors), an energy regeneration system and the corresponding DNA template (Figure 3) [82]. Zimmerman et al. exploited OCFS to express $p$-azidomethyl-Lphenylalanine (pAMF)-displaying antibodies that could then be site-specifically modified with a drug to generate homogeneous ADCs [83]. 

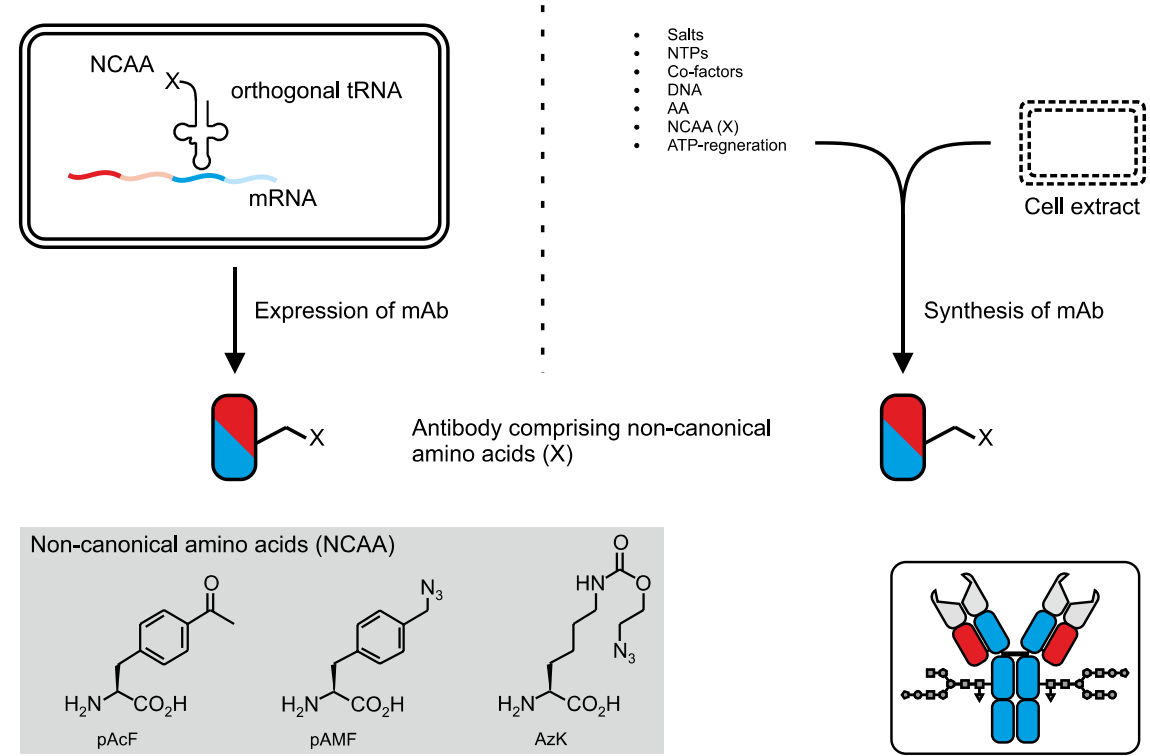

Figure 3. Two different approaches can be employed to incorporate non-canonical amino acids (NCAA) such as $p$-acetylphenylalanine (pAcF), $p$-azidomethyl-L-phenylalanine (pAMF) and azido-lysine (AzK) into an antibody. The cell-based approach uses an orthogonal tRNA/aminoacyl-tRNA synthetase pair to generate a tRNA that carries a NCAA (X) and, hence, an orthogonal functionality is integrated into the antibody. On the contrary, the open cell-free synthesis (OCFS) is used to synthesize, rather than to express, the protein in a cell free environment. It requires cell extract (provides essential organelles), salts, nucleoside triphosphates (NTPs), co-factors, the corresponding DNA, amino acids (AA), NCAA and an energy regeneration system.

\section{Conjugation via the Carbohydrate Moiety}

The carbohydrate moiety of antibodies represents a suitable modification site because its localization is distant from the Fab region's immunoreactive site. Therefore, the chances of impairing the antibody binding affinity, a potential pitfall of chemical conjugation via lysines [21], are minimal. Different strategies to target the glycan for bioconjugation have been developed among which three main methodologies can be distinguished.

\subsection{Chemical Oxidation of Glycans}

Numerous approaches have used sodium periodate as an oxidation reagent to introduce a bioorthogonal aldehyde functionality on the carbohydrate moiety of antibodies. The aldehydes were then used to react with hydrazide- or primary amine functionalized molecules such as biotin [84], toxins [85-88], chelating systems for radiolabeling [89,90] or spacers to link proteins to antibodies [91-94]. The resulting antibody conjugates often lack homogeneity since (i) sodium periodate can cleave any cis-glycol group (Figure 4A) and (ii) the glycosylation pattern of antibodies is heterogeneous (Figure 4B) [95-97]. It has been shown that the rate of oxidation, and as a result the number of available aldehydes, can be controlled to a certain extent by adjusting the concentration of the oxidation reagent, reaction temperature 
or $\mathrm{pH}$ [98-100]. While selective oxidation is possible [88], heterogeneity of the glycosylation pattern remains unchanged and additionally chemical treatment of the antibody may also affect amino acid residues such as serine, threonine, proline and methionine which could ultimately perturb the structure and immunoreactivity of the antibody.

A

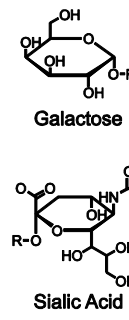

C

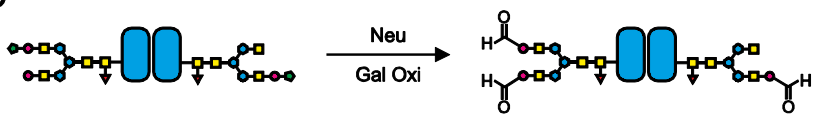

B

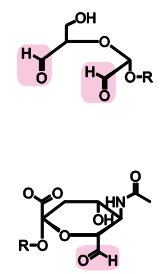

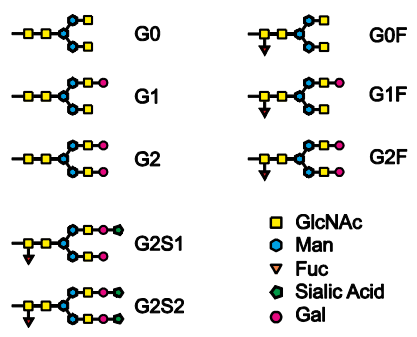
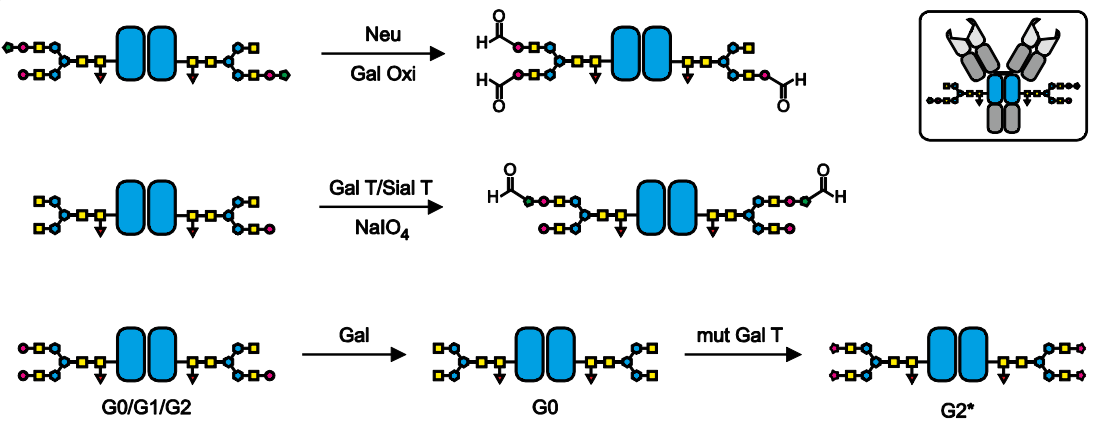

D

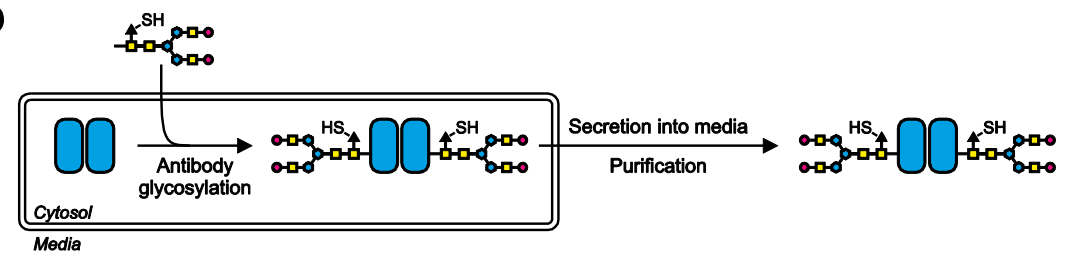

Figure 4. Different strategies to introduce bioorthogonal functionalities onto the carbohydrate moiety for site selective conjugation. (A) Classical chemical approaches use sodium periodate $\left(\mathrm{NaIO}_{4}\right)$ to oxidize cis-glycol groups of e.g., galactose or sialic acid resulting in the formation of an aldehyde functionality (red square). (B) Schematic representation of a selection of different glycoforms that can be found on IgGs (illustrates the heterogeneity of antibody glycosylation patterns). (C) Novel enzymatic methods treat the sugar residue with neuraminidase (Neu) and galactose oxidase (Gal Oxi) which results in the formation of bioorthogonal aldehyde functionalities (not homogeneous). Sequential treatment of the antibody with $\beta 1,4$-galactosyltransferase (Gal T) $\alpha 2,6$-sialyltransferase (Sial T) yields homogeneously sialylated antibodies that can be selectively oxidized to the corresponding aldehyde functionality or used as selective bioorthogonal handle if sialic acid derivatives are used. A more recent method introduces non-natural galactose derivatives by treating the antibody with $\beta$-galactosidase (Gal) and a mutant Gal T (accepts bioorthogonal azide- or keto-galactoses) to yield homogeneous G2 glycan patterns comprising non-natural functionalities $(*)$. (D) Non-canonical thio-fucose derivatives were incorporated into the glycan of antibodies by feeding the cells with the bioorthogonal sugar resulting in expressed antibodies that display thiol functionalities (not homogeneous). 


\subsection{Enzymatic and Chemo-Enzymatic Modification of Glycans}

To overcome the problems of chemical oxidation various enzymatic and chemo-enzymatic approaches have been established (Figure 4C). Solomon et al. treated the carbohydrate moiety concomitantly with neuraminidase and galactose oxidase to generate aldehydes and subsequently compared their enzymatic method to the classical periodate-approach with respect to site-specificity. The enzymatic oxidation was, as expected, more specific than the chemical oxidation because it is restricted to galactose [101], however, as with the chemical oxidation, this approach does not address the fact that each carbohydrate can bear zero $(\mathrm{G} 0)$, one $(\mathrm{G} 1)$ or two terminal galactose $(\mathrm{G} 2)$ units and thus, accomplishing homogeneous antibody conjugates is impossible.

Zhou et al. solved this problem by using a $\beta 1,4$-galactosyltransferase to generate homogeneous G2 glycosylation and a $\alpha 2,6$-sialyltransferase to sialylate the antibody on the galactose units. Selective oxidation of sialic acid yielded aldehyde functionalities which were subsequently reacted with an aminooxy- functionalized toxin to produce homogeneous ADCs [102]. Li et al. exploited the very same approach as Zhou but introduced sialic acid derivatives, which have an azide functionality at the C-9 position, instead of normal sialic acid. The azide functionality was then reacted with various functionalities including a toxin to yield homogeneous antibody conjugates [103].

A slightly different approach consists of an enzymatic two-step procedure to incorporate non-natural glycan moieties. In a first step, terminal galactose units are removed by $\beta 1,4$-galactosidase to yield homogeneous G0 species which are then reglycosylated to a uniform G2 species by a mutant $\beta 1,4-$ galactosyltransferase-mediated attachment of C-2 modified galactoses, e.g., 2-keto-galactose (C2-keto-Gal) or 2-azido-galactose (C2-GalNAz). While Boeggeman et al. applied this technology to develop biotinylated and fluorescently-labeled antibody conjugates [104,105], other groups employed the protocol to generate radioactive antibodies as in vivo imaging agents [106,107] or ADCs [108]. Van Geel and co-workers took this technology one step further by removing the terminal galactose residues and trimming the entire carbohydrate moiety down to its core GlcNAc unit. Analogous to the above described technologies, they then attached galactose derivatives to the core GlcNAc by using the same mutant $\beta 1$,4-galactosyltransferase. To demonstrate the versatility and power of their platform, they used different antibodies, different galactose derivatives, linkers and toxins to generate homogeneous ADCs [109].

\subsection{Metabolic Engineering of the Carbohydrate Moiety}

Instead of modifying the carbohydrate moiety of the purified antibody, Okeley et al. envisaged the introduction of unnatural fucose-derivatives at an earlier stage of the antibody production. Their antibody modification strategy is based on the metabolic incorporation of thio-fucose during the post-translational modification of the antibody by feeding the cells with the non-natural sugar (Figure 4D). The thiolfunctionality could then be used as a bioorthogonal handle to attach a toxin by employing standard thiol-maleimide chemistry [110]. Nevertheless, the incorporation rate varies significantly among different fucose derivatives, which limits the extension of this technology to introduce various bioorthogonal functionalities.

Although it has been demonstrated that the carbohydrate moiety is an attractive multivalent target for bioconjugation, most of the described approaches still suffer from product heterogeneity either caused 
by non-homogeneous glycan patterns or non-quantitative bioconjugation yields. Moreover, it must be considered that antibodies can also be N-glycosylated in their variable region [96,111]. These Fab carbohydrates can be involved in immunomodulation [112] and their composition differs from the Fc glycans [113]. Bioconjugation procedures, as described in this section, will inevitably affect these Fab glycans and as a consequence may influence the antibodies properties.

\section{Conjugation via the $\mathrm{N}$-Terminus}

The lower $\mathrm{pKa}$ of the $\alpha$-amino group (average $\sim 9.5$ ) on amino acids compared to the $\varepsilon$-amino group of lysine (10.5) was exploited to direct acylation reactions to the $\mathrm{N}$-terminus of antibodies. Francis and co-workers used different transamination reagents, based on a 4-pyridinecarboxaldehyde framework, to introduce ketone or aldehyde groups onto the $\mathrm{N}$-termini of various antibodies (Figure 5). The bioorthogonal functionality was then used to site-specifically conjugate aminooxy-functionalized molecules including fluorescent dyes, PEG, or porphyrin to antibodies [114-116]. The clear advantage of this approach is its versatility since it can be directly applied to any given antibody. However, the yield of these two step conjugation reaction is highly dependant on the physical-chemical properties of the corresponding N-terminal amino acid [114] and covers, in case of antibodies, the entire range from $0 \%$ to $70 \%$. Low yields can be improved to a certain extent by substituting the N-terminal amino acid [115]. However, the versatility of the approach would be lost because modification of the antibody sequence on the genetic level is required.
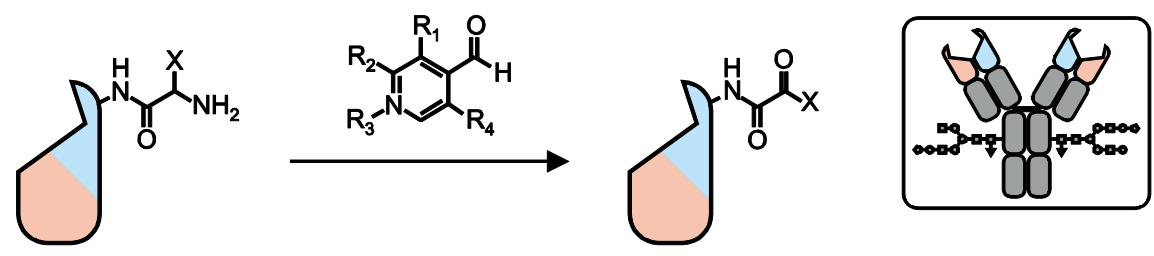

\footnotetext{
Pyridoxal 5'-phosphate: $\mathrm{R}_{1}-\mathrm{OH}, \mathrm{R}_{2}-\mathrm{CH}_{3}, \mathrm{R}_{3}-\mathrm{H}, \mathrm{R}_{4}-\mathrm{CH}_{2} \mathrm{OPO}_{3}{ }^{2-}$ $N$-methylpyridinium-4-carboxaldehyde: $\mathrm{R}_{1}-\mathrm{H}, \mathrm{R}_{2}-\mathrm{H}, \mathrm{R}_{3}-\mathrm{CH}_{3}, \mathrm{R}_{4}-\mathrm{H}$
}

Figure 5. Selective oxidation of the $\alpha$-amino group of the N-terminal amino acid (X) of heavy and light chain using pyridoxal 5'-phosphate or N-methylpyridinium-4carboxaldehyde. This reaction yields bioorthogonal keto- or aldehyde-functionalities, which can then be reacted with aminooxy-functionalized molecules.

\section{Conjugation via Tags}

Enzymes that recognize a specific amino acid tag, usually ranging from four up to 15 residues [117,118] can be exploited for site-specific antibody conjugation. The uniqueness of the tag prevents random modification and allows the site of modification to be exactly determined in a similar manner as the incorporation of additional cysteines or NCAA. Currently, there are three different enzymes that have been exploited to conjugate various functionalities to full-length antibodies. 


\subsection{Formylglycin Generating Enzyme (FGE)}

Formylglycine generating enzyme (FGE) recognizes a tag that comprises a six-residue LCxPxR motif and oxidizes the cysteine to formylglycine (Figure 6A) [119-121]. The bioorthogonal aldehyde functionality can then be reacted specifically with hydrazines and alkoxyamines to form hydrazones and oximes, respectively. Hudak et al. employed this approach to join an antibody to a second protein. The tagged antibody and the tagged protein were first reacted with a cyclooctynes-aminooxy linker and an azido-aminooxy linker respectively and then covalently linked together via a copper-free azide-alkyne cycloaddition reaction that yielded heterobifunctional antibody conjugates [122]. As a problem of hydrazones and oximes is their susceptibility to hydrolysis, Agarwal et al. recently developed a novel aldehyde tag-compatible functionality that is based on an indole framework and reacts with the aldehyde to form an oxacarboline linkage. This bond is stable towards hydrolysis and compatible with their FGEbased antibody bioconjugation approach [123]. As discussed above, the presence of unmodified cysteines on the tag could interfere with other free cysteines or with the folding of the protein [120].

A
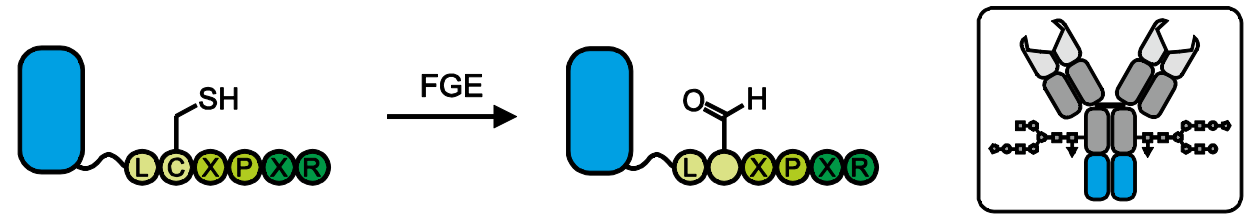

$\mathrm{B}$

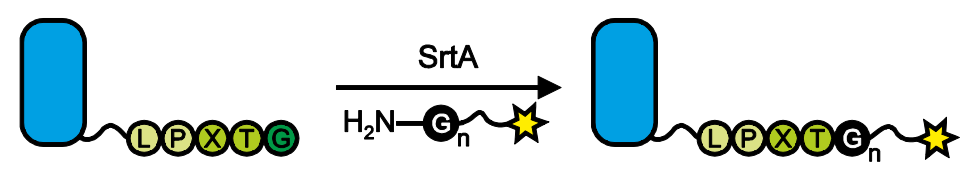

C
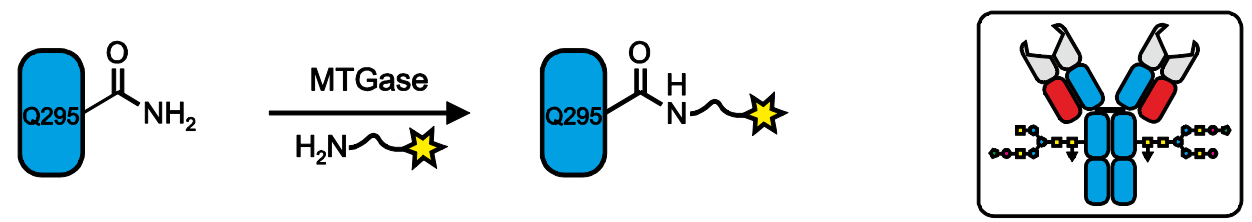

D

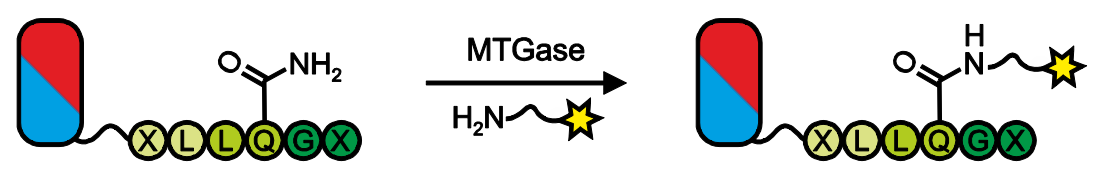

Figure 6. General concepts of antibody conjugation via tags. (A) The formylglycine generating enzyme (FGE) converts the cysteine of a LCXPXR tag into formylglycine, thereby creating a bioorthogonal aldehyde handle for site-specific chemical antibody conjugation. (B) Sortase A (Srt A) mediates that conjugation of an LPXTG motif with a polyglycine-functionalized ligand of interest (yellow star). General scheme of MTGasemediated antibody modification targeting (C) the endogenous glutamine at position 295 or (D) a glutamine-containing tag. 


\subsection{Sortase}

A second tag-based approach for antibody bioconjugation is sortase-mediated transpeptidation (sortagging), which relies on the ability of sortase A, a bacterial transpeptidase from Staphylococcus aureus, to catalyze the ligation between an LPXTG and a polyglycine motif (Figure 6B) [124-126]. Different groups have demonstrated the versatility of this technology by fusing proteins including albumin, a Fab-fragment, an antibody, gelonin and green fluorescent protein (polyglycine tagged) and peptides to an LPETG-tagged antibody [127,128]. At the same time, it is also possible to tag small molecules with one of the two motifs and use them to produce antibody conjugates. Wagner et al. modified LPETG-tagged antibodies with triglycine-functionalized chemical entities that are suitable for copper-free azide-alkyne cycloaddition and subsequently linked two different antibodies to yield bispecific antibody conjugates [129]. Recently, Bellucci et al. described a non-canonical function of sortase A where they replaced the polyglycine with a $\mathrm{WX}_{3} \mathrm{VXVYPKH}$ motif. The introduction of this sequence into the backbone of an antibody enabled them to site-specifically conjugate LPETGfunctionalized biotin to the immunoglobulin via the lysine of $\mathrm{WX}_{3} \mathrm{VXVYPKH}$ [130]. This novel approach overcomes the limitations of classical sortase A mediated bioconjugation that is restricted to the terminal modification of proteins with only one molecule because it is conceivable to incorporate multiple copies of the sequence into the protein at virtually any location.

\subsection{Transglutaminases}

Transglutaminases (TGases, EC 2.3.2.13) are a family of enzymes that catalyze the acyl transfer reaction between the $\gamma$-carboxyamide group of glutamine residues and various primary amines including lysine (transamidation) under the loss of ammonia. Among different members of this enzyme family that have been used for bioconjugation approaches microbial transglutaminase (MTGase) from Streptomyces mobaraensis is the most popular one. First expressed, purified and characterized by Ando et al. [131] MTGase has become an indispensable and versatile tool, particularly for biotechnological technologies including antibody conjugation [132,133].

The first approaches to enzymatically conjugate biotin and fluorescent dyes to antibodies yielded heterogeneous antibody conjugates with regard to the PAR while the site of conjugation could not be determined $[134,135]$. It was not until Jeger et al. discovered a single glutamine in the human IgG heavy chain domain (Q295), which is next to the antibody glycosylation site (N297), to be the sole site of modification for MTGase-mediated bioconjugation. Moreover, they could demonstrate that homogeneous antibody conjugates with a defined stoichiometry, i.e., exactly two payloads per antibody can be accomplished when the antibody was deglycosylated prior to the conjugation (Figure 6C). The introduction of a N297Q mutation enabled them to express an aglycosylated antibody variant that displays four potential acyl-donor sites for MTGase, thereby doubling the number of payloads that can be attached to the antibody [136]. This concept has recently been used to generate ADCs that carry a defined number of toxins per antibody [137,138].

Researches at Rinat-Pfizer developed a slightly different approach by introducing an artificial Gln-tag (XLLQGX, Figure 6D) into an IgG1 that serves as a acyl-donor site for MTGase. Since the tag can be implemented at virtually any position in the backbone of an antibody they were able to investigate 
how the location of the conjugation site influences not only the in vitro, but, more importantly, the in vivo characteristics of the antibody conjugate, a particularly interesting question for ADCs. The tag was incorporated at different sites, enzymatically modified with a toxin and the resulting ADC stability and pharmacokinetics were evaluated. Using this approach they could demonstrate that ADCs where the toxin was attached at different sites exhibited different stabilities and pharmacokinetics when tested in mouse, rat and human plasma and mice and rats, respectively $[139,140]$.

\section{Miscellaneous Conjugation Methods}

\subsection{Conjugation via Fc-Binding Domains (FcBD)}

All previously described bioconjugation methods include the formation of a covalent bond between a specific functionality and an amino acid or carbohydrate moiety. Small domains that bind with high affinity to a conserved sequence in the Fc-domain of antibodies are used to form non-covalent antibody conjugates with a defined site of conjugation and stoichiometry. This approach does not require any modification of the antibody itself and the same domain can be used to readily form bioconjugates with virtually every immunoglobulin of the same isotype/subtype.

\subsubsection{ZZ-Domain}

Among numerous FcBDs, the ZZ-domain-a dimer of the modified immunoglobulin binding site of protein A of Staphylococcus aureus [141]-is the most widely used. Its high-affinity interaction with the Fc part of antibodies [142,143] has been exploited to generate antibody displaying nanocapsules (Figure 7A) that were employed for in vitro targeted delivery of proteins [144] for simultaneous detection of multiple antigens in immunological assays (Western blot analysis, immunocytochemistry, flow cytometric analysis, and immunohistochemistry) [145], for immunosensor chips [146,147], or for the establishment of drug-delivery systems [148]. Benhar and co-workers developed FcBD-based ADCs by genetically fusing the ZZ-domain to Pseudomonas exotoxin A (ZZ-PE38) [149]. Incubation with a corresponding antibody yielded highly toxic non-covalently coupled ADCs (Figure 7B) that have proven their potential by efficiently killing tumor cells in vivo [150-152]. By combining the sortase A mediated protein-protein conjugation technology with the ZZ-domain, Sakamoto et al. demonstrated the utility of FcBDs as versatile adapter molecules for the generation of antibody-protein conjugates [153].

\subsubsection{Photoactivable FcBDs}

Although the binding affinity of the ZZ-domain towards an antibody is high, it still remains a reversible interaction and hence may not be stable enough for applications where conditions such as $\mathrm{pH}$ vary. A possible strategy to covalently link an FcBD to an antibody is to equip the domain with a photoactivable probe, e.g., benzophenone that, upon irradiation, is activated and forms a covalent bond to a closely located amino acid on the immunoglobulin surface (Figure 7C). This methodology has been successfully applied by using various FcBDs including different variants of the monomeric Z-domain [154-157] and a minimal domain of protein G [158]. 
A
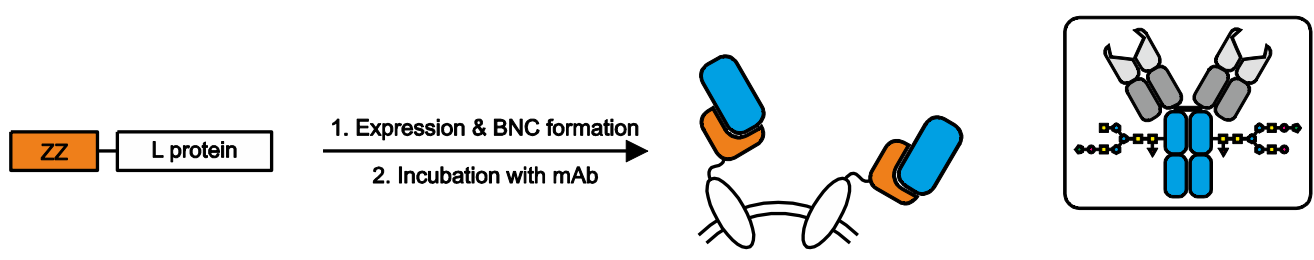

B

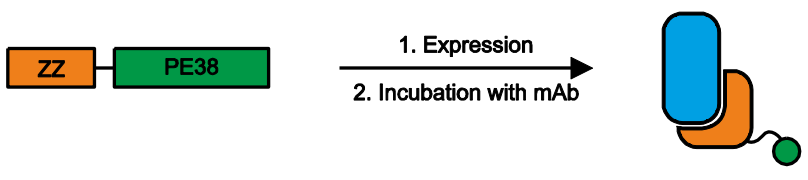

C

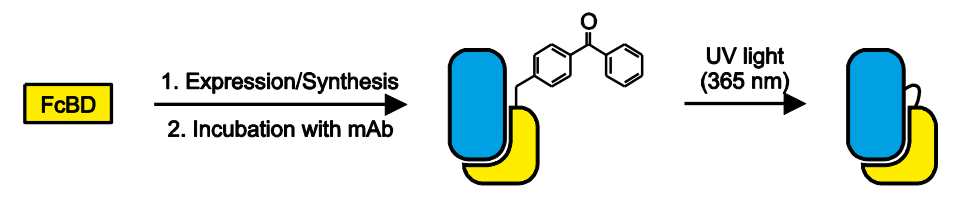

Figure 7. Fc binding domains (FcBD) were exploited as a tool to produce both non-covalent and covalent antibody conjugates. (A) The ZZ-domain (ZZ) is expressed as a fusion with the $\mathrm{L}$ protein from hepatitis $\mathrm{B}$ virus to generate FcBD-bionanocapsules (BNC) that can be decorated with antibodies suitable various in vitro applications. (B) When expressed as a fusion protein with Pseudomonas exotoxin A (PE38), the ZZ-domain can be used to generate ADCs. (C) If FcBDs are endowed with photoactivable chemical groups, e.g., benzophenone it is possible to form covalent antibody conjugates by exposing the non-covalent conjugate to UV light.

\subsection{Bioconjugation via the Nucleotide Binding Site}

Besides the canonical antigen binding sites of an IgG (CDRs), a rather unknown and unconventional nucleotide-binding site can be found in the variable region of immunoglobulins [159]. Pavlinkova et al. were the first to recognize the potential of this binding pocket for site-specific antibody modification. They developed biotin-functionalized nucleotide derivatives that, upon binding, were photoactivated to form a covalent bond to the antibody (Figure 8A) [160,161]. Alves et al. developed this strategy further by using various indole-functionalized ligands comprising biotin, a fluorescent dye, a cyclic peptide and paclitaxel to generate antibody conjugates $[162,163]$. Even though the conjugation site is not very distant from the antigen-binding site, the immunoreactivity of the antibody was not impaired.

\subsection{Catalytic Antibodies}

Catalytic antibodies are immunoglobulins that mechanistically mimic natural enzymes. Barbas and co-workers screened for such antibodies via reactive immunization and could identify antibody catalysts that mimic class I aldolase enzymes [164-167]. In contrast to any conjugation technology previously described, the antibody acts here solely as a carrier protein and has no targeting properties. By fusing a small molecular weight payload (SMWP, e.g., peptide) with a catalytic antibody, it is possible to generate antibody conjugates that combine the highly specific targeting properties of the SMWP and the pharmacokinetic characteristics of an antibody [168-170]. The conjugation is based on the derivatization 
of the pharmacophore with either a diketone, vinylketone or azetidinone functional group that forms a covalent bond with a specific lysine residue in the active site of the catalytic antibody (Figure 8B). This technology has been extensively exploited to develop a variety of novel therapeutics for cancer [171-178], HIV [179], influenza [180], pain [181] or growth hormone (GH) deficiency [182]. It must be reiterated, though, that it is no longer the targeting properties of the antibody that are desired, but their pharmacokinetic characteristics, and, hence, these are not antibody conjugates in the classical sense.

A
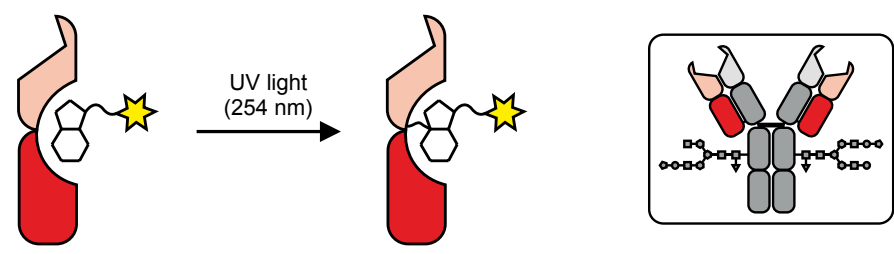

B
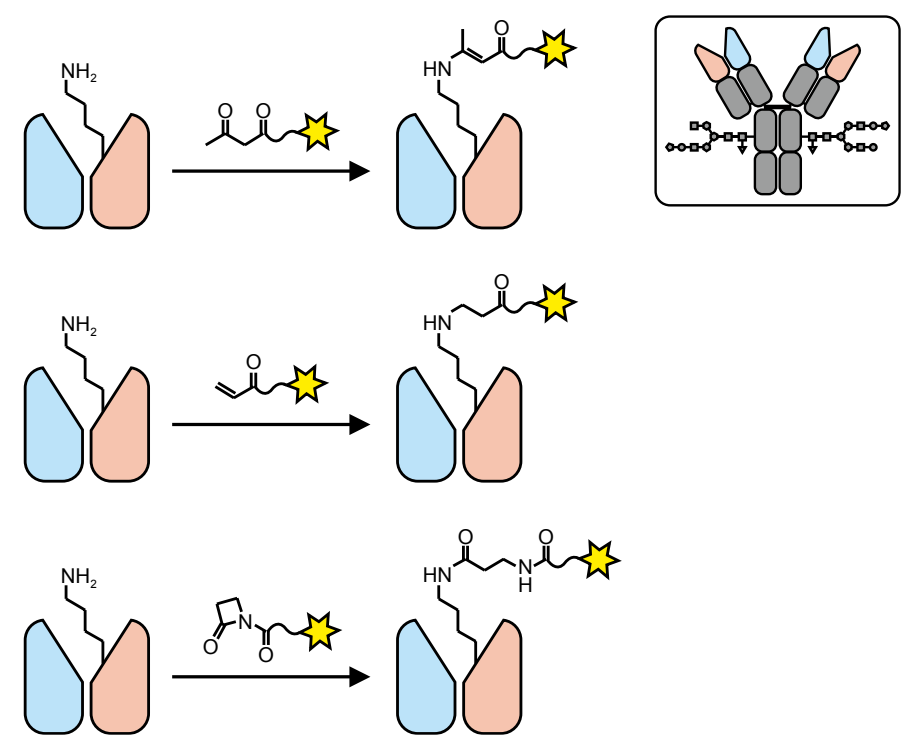

Figure 8. (A) General procedure for photoaffinity labeling of antibodies. A ligand of interest (yellow, star) is functionalized with a nucleotide based chemical entity. Once bound to the nucleotide binding site, irradiation with UV light will activate the nucleotide which results in the formation of a covalent bond. (B) The enzymatic activity of catalytic antibodies results in the formation of a covalent bond between a lysine of the catalytic site and a diketone-, vinylketone- or azetidinone-functionalized small molecular weight payload, e.g., peptide (yellow star).

\section{Conclusions}

At present, antibody conjugation techniques are often associated with the term 'site-specific'. The examples of ADC development outlined in this review clearly demonstrate the necessity for sitespecificity, but a defined stoichiometry of the corresponding cargo is equally, if not even more, important. Site-directed bioconjugation approaches help to investigate variables such as the site of conjugation, nature of payload and linker and choice of antibody format on the in vivo performance of ADCs. It is likely that, in the future, only site-specifically (and stoichiometrically) modified ADCs will be approved by regulating authorities since these techniques enable us to tightly control the conjugation 
reaction to produce highly defined ADCs, and, thus, ensure batch-to-batch reproducibility. It is the opinion of the authors that it is not clear at this point which techniques or combination of techniques are the most appropriate for large-scale ADC production. It should also not be forgotten that classical, non-specific chemical conjugation methods are proven technologies that are easy to use and, in many cases, they are sufficient, e.g., for in vitro studies performed on a daily basis in the laboratory. This review has shown the current scope of technologies for the conjugation of full-length antibodies, but there are numerous bioconjugation methods for different protein scaffolds available. While researchers are spoilt for choice as to the most suitable strategy for their conjugation purpose, it is important to choose the right method that yields antibody conjugates, which are tailor-made for their foreseen use.

\section{Acknowledgments}

The authors would like to thank Laura K. Bailey for help with the manuscript. This work was funded by the Swiss National Science Foundation (SNF Grant No. 132611).

\section{Author Contributions}

Patrick Dennler wrote the manuscript and designed the figures. Eliane Fischer and Roger Schibli reviewed and revised the manuscript.

\section{Conflicts of Interest}

The authors declare no conflict of interest.

\section{References}

1. Köhler, G.; Milstein, C. Continuous cultures of fused cells secreting antibody of predefined specificity. Nature 1975, 256, 495-497.

2. Vacchelli, E.; Aranda, F.; Eggermont, A.; Galon, J.; Sautes-Fridman, C.; Zitvogel, L.; Kroemer, G.; Galluzzi, L. Trial Watch: Tumor-targeting monoclonal antibodies in cancer therapy. Oncoimmunology 2014, 3, e27048.

3. Reichert, J.M. Antibodies to watch in 2015. MAbs 2015, 7, 1-8.

4. Beck, A.; Reichert, J.M. Antibody-drug conjugates: present and future. MAbs 2014, 6, 15-17.

5. Papachristos, A.; Pippa, N.; Demetzos, C.; Sivolapenko, G. Antibody-drug conjugates: A minireview. The synopsis of two approved medicines. Drug Deliv. 2015, 1-5.

6. Kraeber-Bodere, F.; Bodet-Milin, C.; Rousseau, C.; Eugene, T.; Pallardy, A.; Frampas, E.; Carlier, T.; Ferrer, L.; Gaschet, J.; Davodeau, F.; et al. Radioimmunoconjugates for the treatment of cancer. Semin. Oncol. 2014, 41, 613-622.

7. Sapra, P.; Hooper, A.; O'Donnell, C.; Gerber, H.-P. Investigational antibody drug conjugates for solid tumors. Expert Opin. Investig. Drugs 2011, 20, 1131-1180.

8. Flygare, J.; Pillow, T.; Aristoff, P. Antibody-drug conjugates for the treatment of cancer. Chem. Biol. Drug Des. 2013, 81, 113-121.

9. Panowski, S.; Bhakta, S.; Raab, H.; Polakis, P.; Junutula, J.R. Site-specific antibody drug conjugates for cancer therapy. MAbs 2013, 6, 34-45. 
10. Stephanopoulos, N.; Francis, M.B. Choosing an effective protein bioconjugation strategy. Nat. Chem. Biol. 2011, 7, 876-884.

11. Hamblett, K.J.; Senter, P.D.; Chace, D.F.; Sun, M.M.; Lenox, J.; Cerveny, C.G.; Kissler, K.M.; Bernhardt, S.X.; Kopcha, A.K.; Zabinski, R.F.; et al. Effects of drug loading on the antitumor activity of a monoclonal antibody drug conjugate. Clin. Cancer. Res. 2004, 10, 7063-7070.

12. Boswell, C.A.; Mundo, E.E.; Zhang, C.; Bumbaca, D.; Valle, N.R.; Kozak, K.R.; Fourie, A.; Chuh, J.; Koppada, N.; Saad, O.; et al. Impact of drug conjugation on pharmacokinetics and tissue distribution of anti-STEAP1 antibody-drug conjugates in rats. Bioconjug. Chem. 2011, 22, 1994-2004.

13. Jackson, D.; Atkinson, J.; Guevara, C.I.; Zhang, C.; Kery, V.; Moon, S.-J.J.; Virata, C.; Yang, P.; Lowe, C.; Pinkstaff, J.; et al. In vitro and in vivo evaluation of cysteine and site-specific conjugated herceptin antibody-drug conjugates. PloS One 2014, 9, e83865:14

14. Behrens, C.R.; Liu, B. Methods for site-specific drug conjugation to antibodies. $m A b s$ 2013, 6 , 46-53.

15. Kline, T.; Steiner, A.R.; Penta, K.; Sato, A.K.; Hallam, T.J.; Yin, G. Methods to make homogenous antibody drug conjugates. Pharm. Res. 2014, doi: 10.1007/s11095-014-1596-8.

16. Agarwal, P.; Bertozzi, C.R. Site-specific antibody-drug conjugates: The nexus of bioorthogonal chemistry, protein engineering, and drug development. Bioconjug. Chem. 2015, 26, 176-192.

17. Sochaj, A.M.; Swiderska, K.W.; Otlewski, J. Current methods for the synthesis of homogeneous antibody-drug conjugates. Biotechnol. Adv. 2015, doi: 10.1016/j.biotechadv.2015.05.001.

18. Zhou, Q.; Kim, J. Advances in the development of site-specific antibody-drug conjugation. Anticancer Agents Med. Chem. 2015, 15, 828-836.

19. McCombs, J.R.; Owen, S.C. Antibody drug conjugates: Design and selection of linker, payload and conjugation chemistry. AAPS J. 2015, 17, 339-351.

20. Glazer, A.N. Specific chemical modification of proteins. Annu. Rev. Biochem. 1970, 39, 101-130.

21. Ghose, T.I.; Blair, A.H.; Kulkarni, P.N. Preparation of antibody-linked cytotoxic agents. Methods Enzymol. 1983, 93, 280-333.

22. Hermanson, G.T. Bioconjugate Techniques; Academic Press: New York, NY, USA, 2008; pp. 1041-1132.

23. Gauthier, M.A.; Klok, H.-A. Peptide/protein-polymer conjugates: Synthetic strategies and design concepts. Chem. Commun. (Cambridge, U. K.) 2008, 21, 2591-2611.

24. Francis, M.B. New methods for protein bioconjugation. In Chemical Biology; Wiley-VCH Verlag GmbH: Weinheim, Germany, 2008; pp. 593-634.

25. Sletten, E.M.; Bertozzi, C.R. Bioorthogonal chemistry: Fishing for selectivity in a sea of functionality. Angew. Chem. Int. Ed. Engl. 2009, 48, 6974-6998.

26. Mueller, B.M.; Wrasidlo, W.A.; Reisfeld, R.A. Determination of the number of e-amino groups available for conjugation of effector molecules to monoclonal antibodies. Hybridoma 1988, 7 , 453-456.

27. Widdison, W.C.; Wilhelm, S.D.; Cavanagh, E.E.; Whiteman, K.R.; Leece, B.A.; Kovtun, Y.; Goldmacher, V.S.; Xie, H.; Steeves, R.M.; Lutz, R.J.; et al. Semisynthetic maytansine analogues for the targeted treatment of cancer. J. Med. Chem. 2006, 49, 4392-4408. 
28. Wakankar, A.A.; Feeney, M.B.; Rivera, J.; Chen, Y.; Kim, M.; Sharma, V.K.; Wang, Y.J. Physicochemical stability of the antibody-drug conjugate Trastuzumab-DM1: Changes due to modification and conjugation processes. Bioconjug. Chem. 2010, 21, 1588-1595.

29. Siegel, M.M.; Tabei, K.; Kunz, A.; Hollander, I.J.; Hamann, R.R.; Bell, D.H.; Berkenkamp, S.; Hillenkamp, F. Calicheamicin derivatives conjugated to monoclonal antibodies: determination of loading values and distributions by infrared and UV matrix-assisted laser desorption/ionization mass spectrometry and electrospray ionization mass spectrometry. Anal. Chem. 1997, 69, 2716-2726.

30. Adamczyk, M.; Gebler, J.; Shreder, K.; Wu, J. Region-selective labeling of antibodies as determined by electrospray ionization-mass spectrometry (ESI-MS). Bioconjug. Chem. 2000, 11, 557-563.

31. Wang, L.; Amphlett, G.; Blattler, W.A.; Lambert, J.M.; Zhang, W. Structural characterization of the maytansinoid-monoclonal antibody immunoconjugate, huN901-DM1, by mass spectrometry. Protein Sci. 2005, 14, 2436-2446.

32. Hamann, P.R.; Hinman, L.M.; Hollander, I.; Beyer, C.F.; Lindh, D.; Holcomb, R.; Hallett, W.; Tsou, H.R.; Upeslacis, J.; Shochat, D.; et al. Gemtuzumab ozogamicin, a potent and selective anti-CD33 antibody-calicheamicin conjugate for treatment of acute myeloid leukemia. Bioconjug. Chem. 2002, 13, 47-58.

33. Feng, Y.; Zhu, Z.; Chen, W.; Prabakaran, P.; Lin, K.; Dimitrov, D. Conjugates of small molecule drugs with antibodies and other proteins. Biomedicines 2014, 2, 1-13.

34. Hess, C.; Venetz, D.; Neri, D. Emerging classes of armed antibody therapeutics against cancer. Med. Chem. Commun. 2014, 5, 408-431.

35. Kalkhof, S.; Sinz, A. Chances and pitfalls of chemical cross-linking with amine-reactive N-hydroxysuccinimide esters. Anal. Bioanal. Chem. 2008, 392, 305-312.

36. Madler, S.; Bich, C.; Touboul, D.; Zenobi, R. Chemical cross-linking with NHS esters: A systematic study on amino acid reactivities. J. Mass Spectrom. 2009, 44, 694-706.

37. Chih, H.W.; Gikanga, B.; Yang, Y.; Zhang, B. Identification of amino acid residues responsible for the release of free drug from an antibody-drug conjugate utilizing lysine-succinimidyl ester chemistry. J. Pharm. Sci. 2011, 100, 2518-2525.

38. Goto, Y.; Hamaguchi, K. The role of the intrachain disulfide bond in the conformation and stability of the constant fragment of the immunoglobulin light chain. J. Biochem. 1979, 86, 1433-1441.

39. Proba, K.; Honegger, A.; Pluckthun, A. A natural antibody missing a cysteine in VH: consequences for thermodynamic stability and folding. J. Mol. Biol. 1997, 265, 161-172.

40. Thies, M.J.; Talamo, F.; Mayer, M.; Bell, S.; Ruoppolo, M.; Marino, G.; Buchner, J. Folding and oxidation of the antibody domain CH3. J. Mol. Biol. 2002, 319, 1267-1277.

41. McAuley, A.; Jacob, J.; Kolvenbach, C.G.; Westland, K.; Lee, H.J.; Brych, S.R.; Rehder, D.; Kleemann, G.R.; Brems, D.N.; Matsumura, M. Contributions of a disulfide bond to the structure, stability, and dimerization of human IgG1 antibody CH3 domain. Protein Sci. 2008, 17, 95-106.

42. Liu, H.; Chumsae, C.; Gaza-Bulseco, G.; Hurkmans, K.; Radziejewski, C.H. Ranking the susceptibility of disulfide bonds in human IgG1 antibodies by reduction, differential alkylation, and LC-MS analysis. Anal. Chem. 2010, 82, 5219-5226. 
43. Sun, M.M.; Beam, K.S.; Cerveny, C.G.; Hamblett, K.J.; Blackmore, R.S.; Torgov, M.Y.; Handley, F.G.; Ihle, N.C.; Senter, P.D.; Alley, S.C. Reduction-alkylation strategies for the modification of specific monoclonal antibody disulfides. Bioconjug. Chem. 2005, 16, 1282-1290.

44. McDonagh, C.F.; Turcott, E.; Westendorf, L.; Webster, J.B.; Alley, S.C.; Kim, K.; Andreyka, J.; Stone, I.; Hamblett, K.J.; Francisco, J.A.; et al. Engineered antibody-drug conjugates with defined sites and stoichiometries of drug attachment. Protein Eng. Des. Sel. 2006, 19, 299-307.

45. Doronina, S.O.; Toki, B.E.; Torgov, M.Y.; Mendelsohn, B.A.; Cerveny, C.G.; Chace, D.F.; DeBlanc, R.L.; Gearing, R.P.; Bovee, T.D.; Siegall, C.B.; et al. Development of potent monoclonal antibody auristatin conjugates for cancer therapy. Nat. Biotechnol. 2003, 21, 778-784.

46. Cal, P.M.; Bernardes, G.J.; Gois, P.M. Cysteine-selective reactions for antibody conjugation. Angew. Chem. Int. Ed. Engl. 2014, 53, 10585-10587.

47. Patterson, J.T.; Asano, S.; Li, X.; Rader, C.; Barbas, C.F. Improving the serum stability of sitespecific antibody conjugates with sulfone linkers. Bioconjug. Chem. 2014, 25, 1402-1407.

48. Badescu, G.; Bryant, P.; Bird, M.; Henseleit, K.; Swierkosz, J.; Parekh, V.; Tommasi, R.; Pawlisz, E.; Jurlewicz, K.; Farys, M.; et al. Bridging disulfides for stable and defined antibody drug conjugates. Bioconjug. Chem. 2014, 25, 1124-1136.

49. Bryant, P.; Pabst, M.; Badescu, G.; Bird, M.; McDowell, W.; Jamieson, E.; Swierkosz, J.; Jurlewicz, K.; Tommasi, R.; Henseleit, K.; et al. In vitro and In vivo evaluation of cysteine rebridged trastuzumab-MMAE antibody drug conjugates with defined drug-to-antibody ratios. Mol. Pharm. 2015, 12, 1872-1879.

50. Schumacher, F.F.; Nunes, J.P.; Maruani, A.; Chudasama, V.; Smith, M.E.; Chester, K.A.; Baker, J.R.; Caddick, S. Next generation maleimides enable the controlled assembly of antibody-drug conjugates via native disulfide bond bridging. Org. Biomol. Chem. 2014, 12, 7261-7269.

51. Nunes, J.P.; Morais, M.; Vassileva, V.; Robinson, E.; Rajkumar, V.S.; Smith, M.E.; Pedley, R.B.; Caddick, S.; Baker, J.R.; Chudasama, V. Functional native disulfide bridging enables delivery of a potent, stable and targeted antibody-drug conjugate (ADC). Chem. Commun. (Camb.) 2015, 51, 10624-10627.

52. Maruani, A.; Smith, M.E.; Miranda, E.; Chester, K.A.; Chudasama, V.; Caddick, S. A plug-andplay approach to antibody-based therapeutics via a chemoselective dual click strategy. Nat. Commun. 2015, 6, 6645.

53. Lyon, R.P.; Setter, J.R.; Bovee, T.D.; Doronina, S.O.; Hunter, J.H.; Anderson, M.E.; Balasubramanian, C.L.; Duniho, S.M.; Leiske, C.I.; Li, F.; et al. Self-hydrolyzing maleimides improve the stability and pharmacological properties of antibody-drug conjugates. Nat. Biotechnol. 2014, 32, 1059-1062.

54. Tumey, L.N.; Charati, M.; He, T.; Sousa, E.; Ma, D.; Han, X.; Clark, T.; Casavant, J.; Loganzo, F.; Barletta, F.; et al. Mild method for succinimide hydrolysis on ADCs: impact on ADC potency, stability, exposure, and efficacy. Bioconjug. Chem. 2014, 25, 1871-1880.

55. Stimmel, J.B.; Merrill, B.M.; Kuyper, L.F.; Moxham, C.P.; Hutchins, J.T.; Fling, M.E.; Kull, F.C., Jr. Site-specific conjugation on serine right-arrow cysteine variant monoclonal antibodies. J. Biol. Chem. 2000, 275, 30445-30450. 
56. Bhakta, S.; Raab, H.; Junutula, J. Engineering THIOMABs for site-specific conjugation of thiolreactive linkers. In Antibody-Drug Conjugates; Ducry, L., Ed.; Humana Press: New York, NJ, USA, 2013; Volume 1045, pp. 189-203.

57. Junutula, J.R.; Raab, H.; Clark, S.; Bhakta, S.; Leipold, D.D.; Weir, S.; Chen, Y.; Simpson, M.; Tsai, S.P.; Dennis, M.S.; et al. Site-specific conjugation of a cytotoxic drug to an antibody improves the therapeutic index. Nat. Biotechnol. 2008, 26, 925-932.

58. Shen, B.Q.; Xu, K.; Liu, L.; Raab, H.; Bhakta, S.; Kenrick, M.; Parsons-Reponte, K.L.; Tien, J.; $\mathrm{Yu}$, S.F.; Mai, E.; et al. Conjugation site modulates the in vivo stability and therapeutic activity of antibody-drug conjugates. Nat. Biotechnol. 2012, 30, 184-189.

59. Caron, P.C.; Laird, W.; Co, M.S.; Avdalovic, N.M.; Queen, C.; Scheinberg, D.A. Engineered humanized dimeric forms of IgG are more effective antibodies. J. Exp. Med. 1992, 176, 1191-1195.

60. Shopes, B. A genetically engineered human IgG with limited flexibility fully initiates cytolysis via complement. Mol. Immunol. 1993, 30, 603-609.

61. Baldwin, A.D.; Kiick, K.L. Tunable degradation of maleimide-thiol adducts in reducing environments. Bioconjug. Chem. 2011, 22, 1946-1953.

62. Alley, S.C.; Benjamin, D.R.; Jeffrey, S.C.; Okeley, N.M.; Meyer, D.L.; Sanderson, R.J.; Senter, P.D. Contribution of linker stability to the activities of anticancer immunoconjugates. Bioconjug. Chem. 2008, 19, 759-765.

63. Johansson, L.; Chen, C.; Thorell, J.-O.; Fredriksson, A.; Stone-Elander, S.; Gafvelin, G.; Arnér, E. Exploiting the $21 \mathrm{st}$ amino acid-purifying and labeling proteins by selenolate targeting. Nat. Methods 2004, 1, 61-67.

64. Hofer, T.; Skeffington, L.R.; Chapman, C.M.; Rader, C. Molecularly defined antibody conjugation through a selenocysteine interface. Biochemistry 2009, 48, 12047-12057.

65. Hofer, T.; Thomas, J.D.; Burke, T.R., Jr.; Rader, C. An engineered selenocysteine defines a unique class of antibody derivatives. Proc. Natl. Acad. Sci. USA 2008, 105, 12451-12456.

66. Li, X.; Yang, J.; Rader, C. Antibody conjugation via one and two C-terminal selenocysteines. Methods (San Diego, Calif.) 2014, 65, 133-138.

67. Ban, H.; Gavrilyuk, J.; Barbas, C.F., 3rd. Tyrosine bioconjugation through aqueous ene-type reactions: a click-like reaction for tyrosine. J. Am. Chem. Soc. 2010, 132, 1523-1525.

68. Ban, H.; Nagano, M.; Gavrilyuk, J.; Hakamata, W.; Inokuma, T.; Barbas, C. Facile and stabile linkages through tyrosine: Bioconjugation strategies with the tyrosine-click reaction. Bioconjug. Chem. 2013, 24, 520-532.

69. Gavrilyuk, J.; Ban, H.; Nagano, M.; Hakamata, W.; Barbas, C. Formylbenzene diazonium hexafluorophosphate reagent for tyrosine-selective modification of proteins and the introduction of a bioorthogonal aldehyde. Bioconjug. Chem. 2012, 23, 2321-2328.

70. Gavrilyuk, J.; Ban, H.; Uehara, H.; Sirk, S.J.; Saye-Francisco, K.; Cuevas, A.; Zablowsky, E.; Oza, A.; Seaman, M.S.; Burton, D.R.; et al. Antibody conjugation approach enhances breadth and potency of neutralization of anti-HIV-1 antibodies and CD4-IgG. J. Virol. 2013, 87, 4985-4993.

71. Hallam, T.J.; Smider, V.V. Unnatural amino acids in novel antibody conjugates. Future Med. Chem. 2014, 6, 1309-1324.

72. Wang, Q.; Parrish, A.R.; Wang, L. Expanding the genetic code for biological studies. Chem. Biol. 2009, 16, 323-336. 
73. Kim, C.H.; Axup, J.Y.; Schultz, P.G. Protein conjugation with genetically encoded unnatural amino acids. Curr. Opin. Chem. Biol. 2013, 17, 412-419.

74. Axup, J.; Bajjuri, K.; Ritland, M.; Hutchins, B.; Kim, C.; Kazane, S.; Halder, R.; Forsyth, J.; Santidrian, A.; Stafin, K.; et al. Synthesis of site-specific antibody-drug conjugates using unnatural amino acids. Proc. Natl. Acad. Sci. USA 2012, 109, 16101-16106.

75. Xiao, H.; Chatterjee, A.; Choi, S.-H.; Bajjuri, K.M.; Sinha, S.C.; Schultz, P.G. Genetic incorporation of multiple unnatural amino acids into proteins in mammalian cells. Angew. Chem. Int. Ed. Engl. 2013, 52, 14080-14083.

76. Abaturov, L.V.; Nezlin, R.S.; Vengerova, T.I.; Varshavsky, J.M. Conformational studies of immunoglobulin $\mathrm{G}$ and its subunits by the methods of hydrogen-deuterium exchange and infrared spectroscopy. Biochim. Biophys. Acta 1969, 194, 386-396.

77. Calmettes, P.; Cser, L.; Rajnavolgyi, E. Temperature and $\mathrm{pH}$ dependence of immunoglobulin G conformation. Arch. Biochem. Biophys. 1991, 291, 277-283.

78. Ejima, D.; Tsumoto, K.; Fukada, H.; Yumioka, R.; Nagase, K.; Arakawa, T.; Philo, J.S. Effects of acid exposure on the conformation, stability, and aggregation of monoclonal antibodies. Proteins 2007, 66, 954-962.

79. Yin, G.; Garces, E.D.; Yang, J.; Zhang, J.; Tran, C.; Steiner, A.R.; Roos, C.; Bajad, S.; Hudak, S.; Penta, K.; et al. Aglycosylated antibodies and antibody fragments produced in a scalable in vitro transcription-translation system. MAbs 2012, 4, 217-225.

80. Ozawa, K.; Loscha, K.V.; Kuppan, K.V.; Loh, C.T.; Dixon, N.E.; Otting, G. High-yield cell-free protein synthesis for site-specific incorporation of unnatural amino acids at two sites. Biochem. Biophys. Res. Commun. 2012, 418, 652-656.

81. Caschera, F.; Noireaux, V. Synthesis of $2.3 \mathrm{mg} / \mathrm{ml}$ of protein with an all Escherichia coli cell-free transcription-translation system. Biochimie 2014, 99, 162-168.

82. Hong, S.H.; Kwon, Y.-C.C.; Jewett, M.C. Non-standard amino acid incorporation into proteins using Escherichia coli cell-free protein synthesis. Front. Chem. 2014, 2, 34.

83. Zimmerman, E.S.; Heibeck, T.H.; Gill, A.; Li, X.; Murray, C.J.; Madlansacay, M.R.; Tran, C.; Uter, N.T.; Yin, G.; Rivers, P.J.; et al. Production of site-specific antibody-drug conjugates using optimized non-natural amino acids in a cell-free expression system. Bioconjug. Chem. 2014, 25, 351-361.

84. O'Shannessy, D.J.; Dobersen, M.J.; Quarles, R.H. A novel procedure for labeling immunoglobulins by conjugation to oligosaccharide moieties. Immunol. Lett. 1984, 8, 273-277.

85. Kralovec, J.; Spencer, G.; Blair, A.H.; Mammen, M.; Singh, M.; Ghose, T. Synthesis of methotrexate-antibody conjugates by regiospecific coupling and assessment of drug and antitumor activities. J. Med. Chem. 1989, 32, 2426-2431.

86. Laguzza, B.C.; Nichols, C.L.; Briggs, S.L.; Cullinan, G.J.; Johnson, D.A.; Starling, J.J.; Baker, A.L.; Bumol, T.F.; Corvalan, J.R. New antitumor monoclonal antibody-vinca conjugates LY203725 and related compounds: Design, preparation, and representative in vivo activity. J. Med. Chem. 1989, 32, 548-555.

87. Johnson, D.A.; Baker, A.L.; Laguzza, B.C.; Fix, D.V.; Gutowski, M.C. Antitumor activity of L/1C2-4-desacetylvinblastine-3-carboxhydrazide immunoconjugate in xenografts. Cancer Res. 1990, 50, 1790-1794. 
88. Zuberbühler, K.; Casi, G.; Bernardes, G.J.; Neri, D. Fucose-specific conjugation of hydrazide derivatives to a vascular-targeting monoclonal antibody in IgG format. Chem. Commun. (Camb.) 2012, 48, 7100-7102.

89. Ranadive, G.N.; Rosenzweig, H.S.; Epperly, M.W.; Seskey, T.; Bloomer, W.D. A new method of technetium-99m labeling of monoclonal antibodies through sugar residues. A study with TAG-72 specific CC-49 antibody. Nucl. Med. Biol. 1993, 20, 719-726.

90. Rodwell, J.D.; Alvarez, V.L.; Lee, C.; Lopes, A.D.; Goers, J.W.; King, H.D.; Powsner, H.J.; McKearn, T.J. Site-specific covalent modification of monoclonal antibodies: In vitro and in vivo evaluations. Proc. Natl. Acad. Sci. USA 1986, 83, 2632-2636.

91. Husain, M.; Bieniarz, C. Fc site-specific labeling of immunoglobulins with calf intestinal alkaline phosphatase. Bioconjug. Chem. 1994, 5, 482-490.

92. Liang, J.F.; Li, Y.T.; Connell, M.E.; Yang, V.C. Synthesis and characterization of positively charged tPA as a prodrug using heparin/protamine-based drug delivery system. AAPS PharmSci 2000, 2, E7.

93. Liang, J.F.; Park, Y.J.; Song, H.; Li, Y.T.; Yang, V.C. ATTEMPTS: a heparin/protamine-based prodrug approach for delivery of thrombolytic drugs. J. Control. Release 2001, 72, 145-156.

94. Park, Y.-J.; Liang, J.-F.; Song, H.; Li, Y.T.; Naik, S.; Yang, V.C. ATTEMPTS: A heparin/protamine-based triggered release system for the delivery of enzyme drugs without associated side-effects. Adv. Drug Deliv. Rev. 2003, 55, 251-265.

95. Raju, T.S.; Jordan, R.E. Galactosylation variations in marketed therapeutic antibodies. MAbs 2012, 4, 385-391.

96. Zauner, G.; Selman, M.H.; Bondt, A.; Rombouts, Y.; Blank, D.; Deelder, A.M.; Wuhrer, M. Glycoproteomic analysis of antibodies. Mol. Cell. Proteomics 2013, 12, 856-865.

97. Jefferis, R. Glycosylation of recombinant antibody therapeutics. Biotechnol. Prog. 2005, 21, 11-16.

98. Abraham, R.; Moller, D.; Gabel, D.; Senter, P.; Hellstrom, I.; Hellstrom, K.E. The influence of periodate oxidation on monoclonal antibody avidity and immunoreactivity. J. Immunol. Methods 1991, 144, 77-86.

99. Wolfe, C.A.; Hage, D.S. Studies on the rate and control of antibody oxidation by periodate. Anal. Biochem. 1995, 231, 123-130.

100. Hage, D.S.; Wolfe, C.A.; Oates, M.R. Development of a kinetic model to describe the effective rate of antibody oxidation by periodate. Bioconjug. Chem. 1997, 8, 914-920.

101. Solomon, B.; Koppel, R.; Schwartz, F.; Fleminger, G. Enzymic oxidation of monoclonal antibodies by soluble and immobilized bifunctional enzyme complexes. J. Chromatogr. A 1990, 510, 321-329.

102. Zhou, Q.; Stefano, J.E.; Manning, C.; Kyazike, J.; Chen, B.; Gianolio, D.A.; Park, A.; Busch, M.; Bird, J.; Zheng, X.; et al. Site-specific antibody-drug conjugation through glycoengineering. Bioconjug. Chem. 2014, 25, 510-520.

103. Li, X.; Fang, T.; Boons, G.J. Preparation of well-defined antibody-drug conjugates through glycan remodeling and strain-promoted azide-alkyne cycloadditions. Angew. Chem. Int. Ed. Engl. 2014, 53, 7179-7182.

104. Boeggeman, E.; Ramakrishnan, B.; Kilgore, C.; Khidekel, N.; Hsieh-Wilson, L.C.; Simpson, J.T.; Qasba, P.K. Direct identification of nonreducing GlcNAc residues on N-glycans of glycoproteins using a novel chemoenzymatic method. Bioconjug. Chem. 2007, 18, 806-814. 
105. Boeggeman, E.; Ramakrishnan, B.; Pasek, M.; Manzoni, M.; Puri, A.; Loomis, K.H.; Waybright, T.J.; Qasba, P.K. Site specific conjugation of fluoroprobes to the remodeled Fc N-glycans of monoclonal antibodies using mutant glycosyltransferases: Application for cell surface antigen detection. Bioconjug. Chem. 2009, 20, 1228-1236.

106. Zeglis, B.M.; Davis, C.B.; Aggeler, R.; Kang, H.-C.; Chen, A.; Agnew, B.; Lewis, J.S. An enzymemediated methodology for the site-specific radiolabeling of antibodies based on catalyst-free click chemistry. Bioconjug. Chem. 2013, 42, 1057-1067.

107. Zeglis, B.M.; Davis, C.B.; Abdel-Atti, D.; Carlin, S.D.; Chen, A.; Aggeler, R.; Agnew, B.J.; Lewis, J.S. Chemoenzymatic strategy for the synthesis of site-specifically labeled immunoconjugates for multimodal PET and optical imaging. Bioconjug. Chem. 2014, 25, 2123-2128.

108. Zhu, Z.; Ramakrishnan, B.; Li, J.; Wang, Y.; Feng, Y.; Prabakaran, P.; Colantonio, S.; Dyba, M.A.; Qasba, P.K.; Dimitrov, D.S. Site-specific antibody-drug conjugation through an engineered glycotransferase and a chemically reactive sugar. MAbs 2014, 6, 1190-1200.

109. van Geel, R.; Wijdeven, M.A.; Heesbeen, R.; Verkade, J.M.; Wasiel, A.A.; van Berkel, S.S.; van Delft, F.L. Chemoenzymatic conjugation of toxic payloads to the globally conserved N-glycan of native mAbs provides homogeneous and highly efficacious antibody-drug conjugates. Bioconjug. Chem. 2015, doi: 10.1021/acs.bioconjchem.5b00224.

110. Okeley, N.M.; Toki, B.E.; Zhang, X.; Jeffrey, S.C.; Burke, P.J.; Alley, S.C.; Senter, P.D. Metabolic engineering of monoclonal antibody carbohydrates for antibody-drug conjugation. Bioconjug. Chem. 2013, 24, 1650-1655.

111. Vidarsson, G.; Dekkers, G.; Rispens, T. IgG subclasses and allotypes: From structure to effector functions. Front. Immunol. 2014, 5, 520.

112. Arnold, J.N.; Wormald, M.R.; Sim, R.B.; Rudd, P.M.; Dwek, R.A. The impact of glycosylation on the biological function and structure of human immunoglobulins. Annu. Rev. Immunol. 2007, 25, 21-50.

113. Bondt, A.; Rombouts, Y.; Selman, M.H.; Hensbergen, P.J.; Reiding, K.R.; Hazes, J.M.; Dolhain, R.J.; Wuhrer, M. Immunoglobulin G (IgG) Fab glycosylation analysis using a new mass spectrometric high-throughput profiling method reveals pregnancy-associated changes. Mol. Cell. Proteomics 2014, 13, 3029-3039.

114. Scheck, R.A.; Francis, M.B. Regioselective labeling of antibodies through N-terminal transamination. ACS Chem. Biol. 2007, 2, 247-251.

115. Witus, L.S.; Netirojjanakul, C.; Palla, K.S.; Muehl, E.M.; Weng, C.H.; Iavarone, A.T.; Francis, M.B. Site-specific protein transamination using N-methylpyridinium-4-carboxaldehyde. J. Am. Chem. Soc. 2013, 135, 17223-17229.

116. Sack, J.T.; Stephanopoulos, N.; Austin, D.C.; Francis, M.B.; Trimmer, J.S. Antibody-guided photoablation of voltage-gated potassium currents. J. Gen. Physiol. 2013, 142, 315-324.

117. Rabuka, D. Chemoenzymatic methods for site-specific protein modification. Curr. Opin. Chem. Biol. 2010, 14, 790-796.

118. Rashidian, M.; Dozier, J.; Distefano, M. Enzymatic labeling of proteins: techniques and approaches. Bioconjug. Chem. 2013, 24, 1277-1294.

119. Carrico, I.S.; Carlson, B.L.; Bertozzi, C.R. Introducing genetically encoded aldehydes into proteins. Nat. Chem. Biol. 2007, 3, 321-322. 
120. Wu, P.; Shui, W.; Carlson, B.L.; Hu, N.; Rabuka, D.; Lee, J.; Bertozzi, C.R. Site-specific chemical modification of recombinant proteins produced in mammalian cells by using the genetically encoded aldehyde tag. Proc. Natl. Acad. Sci. USA 2009, 106, 3000-3005.

121. Rabuka, D.; Rush, J.; deHart, G.; Wu, P.; Bertozzi, C. Site-specific chemical protein conjugation using genetically encoded aldehyde tags. Nat. Protoc. 2012, 7, 1052-1119.

122. Hudak, J.; Barfield, R.; de Hart, G.; Grob, P.; Nogales, E.; Bertozzi, C.; Rabuka, D. Synthesis of heterobifunctional protein fusions using copper-free click chemistry and the aldehyde tag. Angew. Chem. Int. Ed. Engl. 2012, 51, 4161-4166.

123. Agarwal, P.; van der Weijden, J.; Sletten, E.M.; Rabuka, D.; Bertozzi, C.R. A Pictet-Spengler ligation for protein chemical modification. Proc. Natl. Acad. Sci. USA 2013, 110, 46-51.

124. Parthasarathy, R.; Subramanian, S.; Boder, E.T. Sortase A as a novel molecular "stapler" for sequence-specific protein conjugation. Bioconjug. Chem. 2007, 18, 469-476.

125. Popp, M.W.; Antos, J.M.; Grotenbreg, G.M.; Spooner, E.; Ploegh, H.L. Sortagging: A versatile method for protein labeling. Nat. Chem. Biol. 2007, 3, 707-708.

126. Ritzefeld, M. Sortagging: A robust and efficient chemoenzymatic ligation strategy. Chemistry 2014, 20, 8516-8529.

127. Levary, D.A.; Parthasarathy, R.; Boder, E.T.; Ackerman, M.E. Protein-protein fusion catalyzed by sortase A. PLoS One 2011, 6, e18342:6.

128. Swee, L.K.; Guimaraes, C.P.; Sehrawat, S.; Spooner, E.; Barrasa, M.I.; Ploegh, H.L. Sortasemediated modification of $\alpha$ DEC205 affords optimization of antigen presentation and immunization against a set of viral epitopes. Proc. Natl. Acad. Sci. USA 2013, 110, 1428-1433.

129. Wagner, K.; Kwakkenbos, M.J.; Claassen, Y.B.; Maijoor, K.; Böhne, M.; van der Sluijs, K.F.; Witte, M.D.; van Zoelen, D.J.; Cornelissen, L.A.; Beaumont, T.; et al. Bispecific antibody generated with sortase and click chemistry has broad antiinfluenza virus activity. Proc. Natl. Acad. Sci. USA 2014, 111, 16820-16825.

130. Bellucci, J.J.; Bhattacharyya, J.; Chilkoti, A. A noncanonical function of sortase enables sitespecific conjugation of small molecules to lysine residues in proteins. Angew. Chem. Int. Ed. Engl. 2014, 54, 441-445.

131. Ando, H.; Adachi, M.; Umeda, K.; Matsuura, A.; Nonaka, M.; Uchio, R.; Tanaka, H.; Motoki, M. Purification and characteristics of a novel transglutaminase derived from microorganisms. Agric. Biol. Chem. 1989, 53, 2613-2617.

132. Zhu, Y.; Tramper, J. Novel applications for microbial transglutaminase beyond food processing. Trends Biotechnol. 2008, 26, 559-565.

133. Strop, P. Versatility of microbial transglutaminase. Bioconjug. Chem. 2014, 25, 855-862.

134. Josten, A.; Haalck, L.; Spener, F.; Meusel, M. Use of microbial transglutaminase for the enzymatic biotinylation of antibodies. J. Immunol. Methods 2000, 240, 47-54.

135. Mindt, T.L.; Jungi, V.; Wyss, S.; Friedli, A.; Pla, G.; Novak-Hofer, I.; Grünberg, J.; Schibli, R. Modification of different IgG1 antibodies via glutamine and lysine using bacterial and human tissue transglutaminase. Bioconjug. Chem. 2008, 19, 271-278.

136. Jeger, S.; Zimmermann, K.; Blanc, A.; Gruenberg, J.; Honer, M.; Hunziker, P.; Struthers, H.; Schibli, R. Site-specific and stoichiometric modification of antibodies by bacterial transglutaminase. Angew. Chem. Int. Ed. Engl. 2010, 49, 9995-9997. 
137. Dennler, P.; Chiotellis, A.; Fischer, E.; Bregeon, D.; Belmant, C.; Gauthier, L.; Lhospice, F.; Romagne, F.; Schibli, R. Transglutaminase-based chemo-enzymatic conjugation approach yields homogeneous antibody-drug conjugates. Bioconjug. Chem. 2014, 25, 569-578.

138. Lhospice, F.; Brégeon, D.; Belmant, C.; Dennler, P.; Chiotellis, A.; Fischer, E.; Gauthier, L.; Boëdec, A.; Rispaud, H.; Savard-Chambard, S.; et al. Site-specific conjugation of monomethyl auristatin $\mathrm{E}$ to anti-CD30 antibodies improves their pharmacokinetics and therapeutic index in rodent models. Mol. Pharm. 2015, 12, 1863-1871.

139. Strop, P.; Liu, S.-H.; Dorywalska, M.; Delaria, K.; Dushin, R.; Tran, T.-T.; Ho, W.-H.; Farias, S.; Casas, M.; Abdiche, Y.; et al. Location matters: Site of conjugation modulates stability and pharmacokinetics of antibody drug conjugates. Chem. Biol. 2013, 20, 161-167.

140. Dorywalska, M.; Strop, P.; Melton-Witt, J.A.; Hasa-Moreno, A.; Farias, S.E.; Galindo Casas, M.; Delaria, K.; Lui, V.; Poulsen, K.; Loo, C.; et al. Effect of attachment site on stability of cleavable antibody drug conjugates. Bioconjug. Chem. 2015, 26, 650-659.

141. Nilsson, B.; Moks, T.; Jansson, B.; Abrahmsen, L.; Elmblad, A.; Holmgren, E.; Henrichson, C.; Jones, T.A.; Uhlen, M. A synthetic IgG-binding domain based on staphylococcal protein A. Protein Eng. 1987, 1, 107-113.

142. Forsgren, A.; Sjöquist, J. Protein A from S. Aureus. J. Immunol. 1966, 97, 822-827.

143. Iangone, J.J. Protein A of Staphylococcus aureus and related immunoglobulin receptors produced by Streptococci and Pneumonococci. In Advances in Immunology; Frank, J.D., Henry, G.K., Eds.; Academic Press: New York, NJ, USA, 1982; Volume 32, pp. 157-252.

144. Kurata, N.; Shishido, T.; Muraoka, M.; Tanaka, T.; Ogino, C.; Fukuda, H.; Kondo, A. Specific protein delivery to target cells by antibody-displaying bionanocapsules. J. Biochem. 2008, 144, 701-707.

145. Iijima, M.; Matsuzaki, T.; Yoshimoto, N.; Niimi, T.; Tanizawa, K.; Kuroda, S.I. Fluorophorelabeled nanocapsules displaying IgG Fc-binding domains for the simultaneous detection of multiple antigens. Biomaterials 2011, 32, 9011-9031.

146. Iijima, M.; Kadoya, H.; Hatahira, S.; Hiramatsu, S.; Jung, G.; Martin, A.; Quinn, J.; Jung, J.; Jeong, S.-Y.; Choi, E.; et al. Nanocapsules incorporating IgG Fc-binding domain derived from Staphylococcus aureus protein A for displaying IgGs on immunosensor chips. Biomaterials 2011, $32,1455-1519$.

147. Iijima, M.; Somiya, M.; Yoshimoto, N.; Niimi, T.; Kuroda, S.I. Nano-visualization of orientedimmobilized IgGs on immunosensors by high-speed atomic force microscopy. Sci. Rep. 2012, 2, 790.

148. Tsutsui, Y.; Tomizawa, K.; Nagita, M.; Michiue, H.; Nishiki, T.-I.; Ohmori, I.; Seno, M.; Matsui, H. Development of bionanocapsules targeting brain tumors. J. Control. Release 2007, 122, 159-164.

149. Mazor, Y.; Barnea, I.; Keydar, I.; Benhar, I. Antibody internalization studied using a novel IgG binding toxin fusion. J. Immunol. Methods 2007, 321, 41-59.

150. Mazor, Y.; Noy, R.; Wels, W.S.; Benhar, I. chFRP5-ZZ-PE38, a large IgG-toxin immunoconjugate outperforms the corresponding smaller FRP5(Fv)-ETA immunotoxin in eradicating ErbB2expressing tumor xenografts. Cancer Lett. 2007, 257, 124-135.

151. Shapira, S.; Shapira, A.; Starr, A.; Kazanov, D.; Kraus, S.; Benhar, I.; Arber, N. An immunoconjugate of anti-CD24 and Pseudomonas exotoxin selectively kills human colorectal tumors in mice. Gastroenterology 2011, 140, 935-946. 
152. Barnea, I.; Ben-Yosef, R.; Karaush, V.; Benhar, I.; Vexler, A. Targeting EGFR-positive cancer cells with cetuximab-ZZ-PE38: Results of in vitro and in vivo studies. Head Neck 2013, 35, 1171-1177.

153. Sakamoto, T.; Sawamoto, S.; Tanaka, T.; Fukuda, H.; Kondo, A. Enzyme-mediated site-specific antibody-protein modification using a ZZ domain as a linker. Bioconjug. Chem. 2010, 21, 2227-2233.

154. Konrad, A.; Karlstrom, A.E.; Hober, S. Covalent immunoglobulin labeling through a photoactivable synthetic $Z$ domain. Bioconjug. Chem. 2011, 22, 2395-2403.

155. Yu, F.; Järver, P.; Nygren, P.-Å.A. Tailor-making a protein a-derived domain for efficient site-specific photocoupling to Fc of mouse IgG1. PLoS One 2013, 8, e56597:11.

156. Perols, A.; Karlström, A.E. Site-specific photoconjugation of antibodies using chemically synthesized IgG-binding domains. Bioconjug. Chem. 2014, 25, 481-488.

157. Hui, J.Z.; Tsourkas, A. Optimization of photoactive protein $Z$ for fast and efficient site-specific conjugation of native IgG. Bioconjug. Chem. 2014, 25, 1709-1719.

158. Jung, Y.; Lee, J.M.; Kim, J.W.; Yoon, J.; Cho, H.; Chung, B.H. Photoactivable antibody binding protein: site-selective and covalent coupling of antibody. Anal. Chem. 2009, 81, 936-942.

159. Rajagopalan, K.; Pavlinkova, G.; Levy, S.; Pokkuluri, P.R.; Schiffer, M.; Haley, B.E.; Kohler, H. Novel unconventional binding site in the variable region of immunoglobulins. Proc. Natl. Acad. Sci. USA 1996, 93, 6019-6024.

160. Pavlinkova, G.; Rajagopalan, K.; Muller, S.; Chavan, A.; Sievert, G.; Lou, D.; O'Toole, C.; Haley, B.; Kohler, H. Site-specific photobiotinylation of immunoglobulins, fragments and light chain dimers. J. Immunol. Methods 1997, 201, 77-88.

161. Pavlinkova, G.; Lou, D.; Kohler, H. Site-specific photobiotinylation of antibodies, light chains, and immunoglobulin fragments. Methods 2000, 22, 44-48.

162. Alves, N.J.; Champion, M.M.; Stefanick, J.F.; Handlogten, M.W.; Moustakas, D.T.; Shi, Y.; Shaw, B.F.; Navari, R.M.; Kiziltepe, T.; Bilgicer, B. Selective photocrosslinking of functional ligands to antibodies via the conserved nucleotide binding site. Biomaterials 2013, 34, 5700-5710.

163. Alves, N.J.; Mustafaoglu, N.; Bilgicer, B. Conjugation of a reactive thiol at the nucleotide binding site for site-specific antibody functionalization. Bioconjug. Chem. 2014, 25, 1198-1202.

164. Wagner, J.; Lerner, R.; Barbas, C. Efficient aldolase catalytic antibodies that use the enamine mechanism of natural enzymes. Science 1995, 270, 1797-1800.

165. Barbas, C.; Heine, A.; Zhong, G.; Hoffmann, T.; Gramatikova, S.; Björnestedt, R.; List, B.; Anderson, J.; Stura, E.; Wilson, I.; et al. Immune versus natural selection: antibody aldolases with enzymic rates but broader scope. Science 1997, 278, 2085-2092.

166. Tanaka, F.; Almer, H.; Lerner, R.A.; Barbas, C.F. Catalytic single-chain antibodies possessing $\beta$-lactamase activity selected from a phage displayed combinatorial library using a mechanismbased inhibitor. Tetrahedron Lett. 1999, 40, 8063-8066.

167. Tanaka, F.; Barbas, C. Reactive immunization: A unique approach to catalytic antibodies. J. Immunol. Methods 2002, 269, 67-79.

168. Sinha, S.C.; Das, S.; Li, L.S.; Lerner, R.A.; Barbas, C.F., 3rd. Preparation of integrin alpha(v)beta3-targeting Ab 38C2 constructs. Nat. Protoc. 2007, 2, 449-456.

169. Bhat, A.; Laurent, O.; Lappe, R. CovX-Bodies. In Fusion Protein Technologies for Biopharmaceuticals; John Wiley \& Sons, Inc.: Hoboken, NJ, USA, 2013; pp. 571-582. 
170. Rader, C. Chemically programmed antibodies. Trends Biotechnol. 2014, 32, 186-197.

171. Rader, C.; Sinha, S.; Popkov, M.; Lerner, R.; Barbas, C. Chemically programmed monoclonal antibodies for cancer therapy: adaptor immunotherapy based on a covalent antibody catalyst. Proc. Natl. Acad. Sci. USA 2003, 100, 5396-5400.

172. Doppalapudi, V.; Tryder, N.; Li, L.; Aja, T.; Griffith, D.; Liao, F.-F.; Roxas, G.; Ramprasad, M.; Bradshaw, C.; Barbas, C. Chemically programmed antibodies: Endothelin receptor targeting CovX-Bodies. Bioorg. Med. Chem. Lett. 2007, 17, 501-506.

173. Coronella, J.; Li, L.; Johnson, K.; Pirie-Shepherd, S.; Roxas, G.; Levin, N. Selective activity against proliferating tumor endothelial cells by CVX-22, a thrombospondin-1 mimetic CovX-Body. Anticancer Res. 2009, 29, 2243-2252.

174. Doppalapudi, V.; Huang, J.; Liu, D.; Jin, P.; Liu, B.; Li, L.; Desharnais, J.; Hagen, C.; Levin, N.; Shields, M.; et al. Chemical generation of bispecific antibodies. Proc. Natl. Acad. Sci. USA 2010, 107, 22611-22616.

175. Li, L.; Leedom, T.A.; Do, J.; Huang, H.; Lai, J.; Johnson, K.; Osothprarop, T.F.; Rizzo, J.D.; Doppalapudi, V.R.; Bradshaw, C.W.; et al. Antitumor efficacy of a thrombospondin 1 mimetic CovX-body. Transl. Oncol. 2011, 4, 249-257.

176. Goswami, R.K.; Bajjuri, K.M.; Forsyth, J.S.; Das, S.; Hassenpflug, W.; Huang, Z.Z.; Lerner, R.A.; Felding-Habermann, B.; Sinha, S.C. Chemically programmed antibodies targeting multiple alpha(v) integrins and their effects on tumor-related functions in vitro. Bioconjug. Chem. 2011, 22, $1535-1544$.

177. Goswami, R.K.; Liu, Y.; Liu, C.; Lerner, R.A.; Sinha, S.C. Synthesis and evaluation of the aldolase antibody-derived chemical-antibodies targeting alpha5betal integrin. Mol. Pharm. 2013, 10, $538-543$.

178. Liu, Y.; Goswami, R.K.; Liu, C.; Sinha, S.C. Chemically programmed bispecific antibody targeting legumain protease and alphavbeta3 integrin mediates strong antitumor effects. Mol. Pharm. 2015, 12, 2544-2550.

179. Sato, S.; Inokuma, T.; Otsubo, N.; Burton, D.R.; Barbas, C.F., 3rd. Chemically programmed antibodies as HIV-1 attachment inhibitors. ACS Med. Chem. Lett. 2013, 4, 460-465.

180. Hayakawa, M.; Toda, N.; Carrillo, N.; Thornburg, N.J.; Crowe, J.E., Jr.; Barbas, C.F., 3rd. A chemically programmed antibody is a long-lasting and potent inhibitor of influenza neuraminidase. ChemBioChem 2012, 13, 2191-2195.

181. Roberts, L.; Brady, K.; Brown, A.; Davey, D.; Feng, L.; Huang, H.; Liu, D.; Malet, L.; McMurray, G.; Phelan, A.; et al. Kappa agonist CovX-Bodies. Bioorg. Med. Chem. Lett. 2012, 22, 4173-4178.

182. Palanki, M.S.S.; Bhat, A.; Bolanos, B.; Brunel, F.; Del Rosario, J.; Dettling, D.; Horn, M.; Lappe, R.; Preston, R.; Sievers, A.; et al. Development of a long acting human growth hormone analog suitable for once a week dosing. Bioorg. Med. Chem. Lett. 2013, 23, 402-406.

(C) 2015 by the authors; licensee MDPI, Basel, Switzerland. This article is an open access article distributed under the terms and conditions of the Creative Commons Attribution license (http://creativecommons.org/licenses/by/4.0/). 